УДК 551.311.231:553.086

\title{
ХАРАКТЕР РАСПРЕДЕЛЕНИЯ ФОСФАТОВ В ЗОЛОТОНОСНЫХ КОРАХ ВЫВЕТРИВАНИЯ ТОМСКОГО РАЙОНА
}

\author{
Янченко Ольга Михайловна', \\ olmininayanchenko@mail.ru

\section{Тимкин Тимофей Васильевич1,} \\ timkin@tpu.ru
}

\section{Ворошилов Валерий Гаврилович1, v_g_v@tpu.ru}

\section{Якич Тамара Юрьевна 1 , cherkasovatu@tpu.ru}

\author{
Мансур Зиаии', \\ m.ziaii47@gmail.com \\ 1 Национальный исследовательский Томский политехнический университет, \\ Россия, 634050, г. Томск, пр. Ленина, 30. \\ 2 Шахрудский технологический университет, \\ Иран, 3619995161, Болвар Данешка, Шахруд.
}

В Томском районе коры выветривания развиты очень широко, установлена их золотоносность, но детального изучения минерального состава ранее не проводилось. Актуальность исследования обусловлена необходимостью выявления условий формирования кор выветривания и установления закономерностей накопления в них широкого круга минералов.

Цель: изучение морфологических и химических особенностей, парагенетических ассоциаций и распространения минералов группы фосфратов, разделение на первичные, преобразованные и новообразованные, использование фосфратов в качестве минералов-индикаторов условий формирования кор выветривания и связи их с распространением золота.

объект: остаточные и переотложенные коры выветривания Томского района и содержащиеся в них минералы группы фосçamoв.

Методы. Кристалломорфоологические особенности минералов группы фосфратов, их парагенетические ассоциации изучались микроскопически при помощи стереомикроскопа OLYMPUS SZX10, химический состав минералов определялся на РФА микроскоne HORIBA X-Ray Analytical Microscope XGT 7200 и сканирующем электронном микроскоne TESCAN VEGA 3 SBU с ЭДC OXFORD X-Max 50.

Результаты. В корах выветривания Томского района установлены: 1) фросфраты группы апатита, 2) ортофроссраты редкоземельных элементов и тория и 3) алюмофоосфаты группы крандаллита. По генетическому признаку фросфатные минералы разделены на группы: а) первичные терригенные фосфраты, устойчивые в корах выветривания и выделившиеся при разрушении коренных пород (монацит, ксенотим, апатит), б) преобразованные, измененные в процессе выветривания (монацит), и в) новообразованные, образованные в процессе формирования кор выветривания (монацит, куларит, фрлоренсит, крандаллит, гояцит, горсейксит, плюмбогуммит). Установленные в различных зонах коры выветривания ассоциации фооссратов большей частью представляют собой звенья последовательного преобразования минералов от кальциевых и редкоземельных фоосфатов к алюминиевым, указывающего на возрастание кислотности среды минералообразования. В верхней части зоны гидролиза остаточной коры выветривания отмечается наибольщее накопление золота.

\section{Ключевые слова:}

Фосфраты, кора выветривания, минералогический анализ, сканирующая электронная микроскопия, Колывань-Томская складчатая зона, Томский район.

\section{Введение}

В настоящее время в природе известно около 200 минералов, содержащих пятиокись фосфора $\left(\mathrm{P}_{2} \mathrm{O}_{5}\right)$ в количестве $1 \%$ и более [1-6]. Фосфор как химический элемент может быть либо отрицательно трехвалентным, либо положительно пятивалентным. В земной коре содержится около 0,12\% (масс.) фосфора в связанном состоянии в виде солей - фосфатов. В состав фосфатов элемент входит в высшем валентном состоянии $\mathrm{P}^{5+}$, связываясь с кислородом и образуя комплексный анион $\left[\mathrm{PO}_{4}\right]^{3-}$. Основные природные соединения фосфора - фосфаты кальция $\mathrm{Ca}_{5}\left[\mathrm{PO}_{4}, \mathrm{CO}_{3}\right]_{3}(\mathrm{~F}, \mathrm{Cl}, \mathrm{OH})$ (минералы группы апатита) [2]. Фосфаты и родствен- ные им минералы - сравнительно сложные по составу соединения, поэтому кристаллизуются в низших сингониях. В соответствии с общим химизмом и количеством главных катионов формулы фосфатов сводятся к следующим типам: $\mathrm{A}_{\mathrm{m}}\left[\mathrm{XO}_{4}\right]_{\mathrm{p}}, \mathrm{A}_{\mathrm{m}}\left[\mathrm{XO}_{4}\right]_{\mathrm{p}} \mathrm{Z}_{\mathrm{q}} \cdot \mathrm{H}_{2} \mathrm{O}$ и $\mathrm{A}_{\mathrm{m}} \mathrm{B}_{\mathrm{n}}\left[\mathrm{XO}_{4}\right]_{\mathrm{p}} \mathrm{Z}_{\mathrm{q}} \cdot \mathrm{H}_{2} \mathrm{O}$. Второй тип соответствует двойным соединениям. $\mathrm{B}$ обобщенных формулах группа $\mathrm{XO}_{4}$ представлена $\mathrm{PO}_{4}{ }^{3-}$ либо добавочными анионами $\mathrm{SO}_{4}{ }^{2-}$, $\mathrm{SiO}_{4}{ }^{2-}, \mathrm{AsO}_{4}{ }^{3-}, \mathrm{CO}_{3}{ }^{2-}, \mathrm{SbO}_{4}{ }^{3-}, \mathrm{CrO}_{4}{ }^{2-}, \mathrm{Z}-\mathrm{OH}, \mathrm{F}, \mathrm{Cl}$ или O; A, В - металлы [3]. Широкое распространение фосфатных минералов в различных геологических средах и уникальные химические особенности привлекают к ним внимание ученых на протяжении многих лет. Не- 
смотря на это, вопросы изучения фосфатных минералов остаются актуальными в аспекте их использования в различных отраслях [7-13], для палеогеографических реконструкций и расшифровки условий образования горных пород $[14,15]$. С прикладной точки зрения основная область применения фосфатов - это сельское хозяйство, где они используются в качестве минеральных удобрений $[12,13,16-20]$, достаточно широко фосфаты применяются также в чёрной и цветной металлургии [21-23], в производстве керамики и стекла [24-26]. Фосфатные минералы формируются в абсолютном большинстве геохимических обстановок поэтому являются ценными индикаторами режима осадконакопления [27, 28] взаимодействия этих осадков с магматическими породами в процессе рудообразования [29], а некоторые из них могут служить для геохронологической датировки абсолютного геологического возраста U-Th-Pb методом [30-32]. Этот далеко неполный перечень типоморфных особенностей фосфатов указывает на важность исследования минералов этой группы в различных геологических обстановках.

В Томском районе коры выветривания развиты очень широко. В результате геологоразведочных работ, вы- полненных ООО ГРК «Геосфера» в 2013-2015 гг. в пределах Колбихинской площади, и проведенных в дальнейшем научных исследований установлена 30лотоносность кор выветривания [33-35]. Данная статья посвящена детальному исследованию минералов группы фосфатов в золотоносных корах выветривания Томского района. Изучении тонкой минералогии нередко играет важную роль при уточнии процессов рудообразования и технологий извлечения золота [36-38].

Цель работы заключается в изучении морфологических и химических особенностей, парагенетических ассоциаций и распространения минералов группы фосфатов, разделении на первичные, преобразованные и новообразованные и использовании их в качестве минералов-индикаторов условий формирования кор выветривания.

\section{Объект исследования}

Объектом исследования послужили мел-палеогеновые золотоносные коры выветривания Колбихинской перспективной площади. Площадь располагается в Томской области, в 25 км к востоку от г. Томска (рис. 1, $a, b)$.
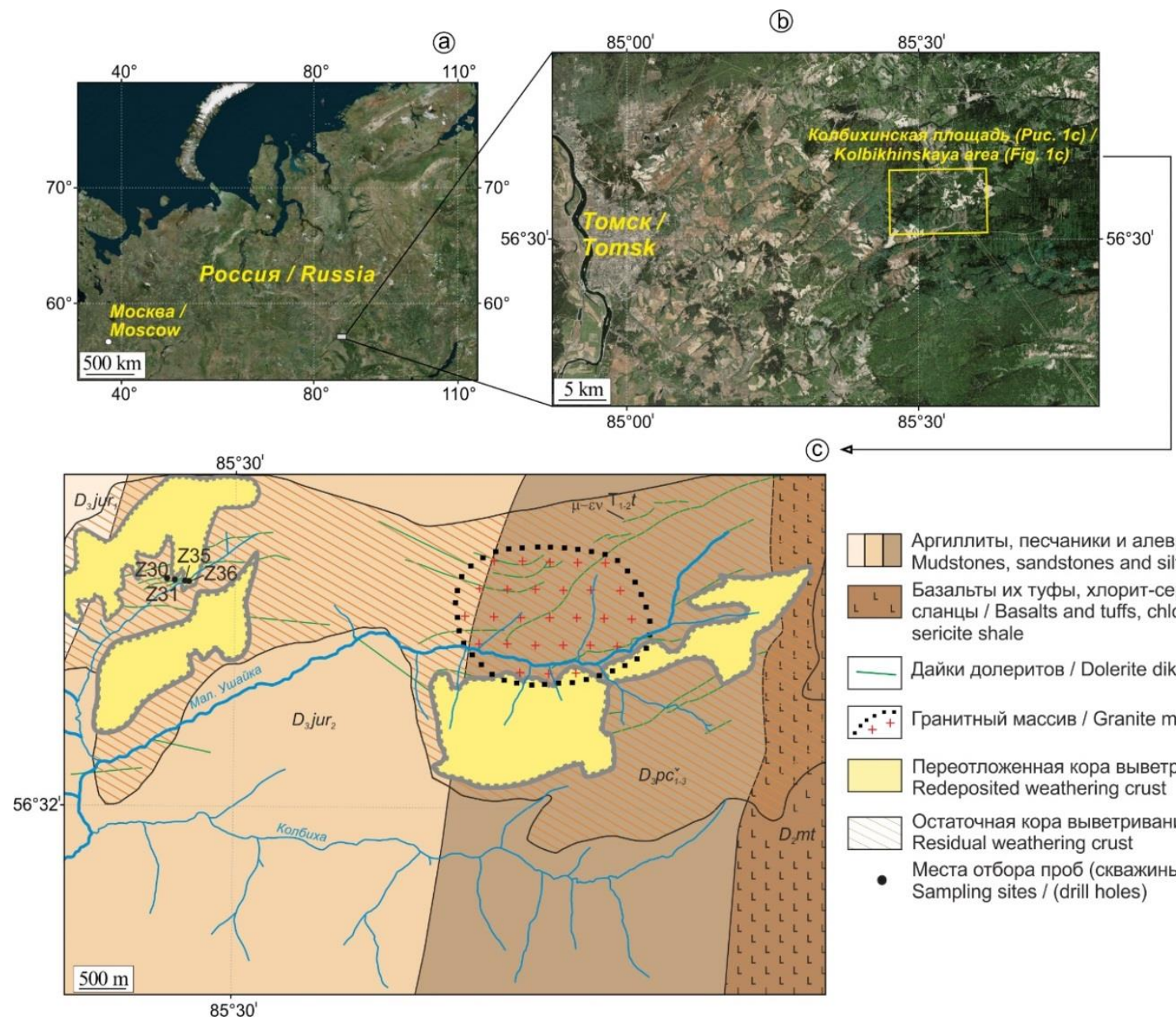

Аргиллиты, песчаники и алевролиты Mudstones, sandstones and siltstones Базальты их туфы, хлорит-серицитовы сланцы / Basalts and tuffs, chloritesericite shale

—— Дайки долеритов / Dolerite dikes $\therefore \because$ Гранитный массив / Granite massif

— Переотложенная кора выветривания / Redeposited weathering crust

Остаточная кора выветривания / Residual weathering crust

- Места отбора проб (скважины)/ Sampling sites / (drill holes)

Pис. 1. a, b) обзорные схемы расположения изучаемого района; с) геологическая карта Колбихинской площади с областями распространения площадных кор выветривания

Fig. 1. a, b) overview diagrams of the study area location; c) geological map of the Kolbikhinskaya area with areas of distribution of areal weathering crusts 


\section{Геологическое строение}

В региональном плане Томский район находится в зоне сочленения крупных геологических структур Колывань-Томской складчатой зоны, ЗападноСибирской плиты и Кузнецкого Алатау.

Коры выветривания сформированы по вулканогенным и терригенным породам и дайкам различного состава (рис. 1, c). Вулканогенные породы среднедевонского возраста представлены отложениями митрофановской свиты $\left(\mathrm{D}_{2} m t\right)$, сложенной преимущественно лавами базальтов, базальтовых порфиритов и их туфами, в подчиненном количестве в составе наблюдаются кислые вулканиты (риолиты, риодациты), линзы известняков и известковистые туфоосадочные породы. В зонах повышенной тектонической проницаемости породы свиты преобразованы в метабазальты и метаморфизованы до хлорит-серицитовых сланцев. Терригенные породы на площади работ представлены пачинской, юргинской свитами, нерасчлененной саламатовской и ярской толщей, лагерносадской и басандайской свитами. Пачинская свита $\left(\mathrm{D}_{3} p \check{c}\right)$ подразделена на три подсвиты. В составе нижней подсвиты доминируют аргиллиты кремнистого состава с тонкими прослоями алевролитов и слабосортированных кварцполевошпатовых песчаников с незначительным количеством туфогенного материала. Средняя подсвита представлена битуминозными аргиллитами и алевролитами с конкрециями фосфоритов. Верхняя подсвита сложена серыми алевролитами с редкими прослоями глинистых и алевритистых известняков. В зонах тектонических нарушений породы свиты преобразованы в филлиты. Юргинская свита $\left(\mathrm{D}_{3} j u r\right)$ сложена породами двух подсвит. В составе нижней подсвиты наблюдаются мелко-, средне- грубозернистые, гравелитистые кварц-полевошпатовые, полимиктовые песчаники с подчиненными прослоями алевролитов, аргиллитов и глинистых сланцев. В состав саламатовской и ярской толщи $\left(\mathrm{D}_{3} s l-\mathrm{C}_{1} j a r\right)$ входят алеврито-глинистые, известково-глинистые, углеродисто-глинистые сланцы и глинистые, слабоизвестковистые алевролиты. В зонах метаморфизма породы часто филлитизированы. В составе толщи наблюдаются маломощные прослои тонко- и мелкозернистых известковистых полевошпаткварцевых песчаников. Лагерносадская свита $\left(\mathrm{C}_{1} l g\right)$ представлена алеврито-глинистыми, иногда углистоглинистыми сланцами с прослоями мелкозернистых песчаников и алевролитов. Басандайская свита $\left(\mathrm{C}_{1-2} b s\right)$ представлена средне-, мелко- и крупнозернистыми, массивными песчаниками с кварц-полевошпатовым, аркозовым иногда полимиктовым составом с примесью известковистого материала в цементе, в подчиненном количестве встречаются прослои алевролитов и глинистых сланцев.

Интрузивные образования представлены дайками томского ареала изылинского базитового комплекса $\left(\mu-\varepsilon v T_{1-2} t\right)$ (рис. $\left.1, c\right)$. Дайки характеризуются значительным петрографическим разнообразием пород. Среди них выделяются долериты, монцониты и гибридные породы. Возраст даек Томского района ранне-среднетриасовый, что обосновывается их сход- ством с кузбасскими траппами, секущим положением по отношению к складчатым структурам КолываньТомской зоны и изотопно-геохронологическими данными (243-238 млн лет).

По генезису образовавшиеся коры выветривания делятся на остаточные (ОКВ) и переотложенные (ПКВ), по морфологии распространения - на площадные и линейные (рис. $1, c)$.

Площадные и линейные остаточные коры выветривания имеют зональное строение. В нижней части остаточных кор выветривания всегда залегает горизонт слабовыветрелых трещиноватых коренных пород (зона дезинтеграции), замещенных по трещинам гидрослюдами и хлоритом. Отмечается, что в строении площадных кор выветривания, помимо зоны дезинтеграции, выделяется зона гидратации, представленная преимущественно гидрослюдистыми глинами с дресвой и щебнем выветрелых пород и кварца. Мощность площадных кор выветривания достигает $10 \mathrm{M}$.

Линейные коры выветривания связаны с зонами повышенной тектонической проницаемости палеозойских пород, которые часто приурочены к участкам пересечения дайковых поясов с зонами трещиноватости и разрывных нарушений, вмещающими послойную кварцевую минерализацию. В строении линейных кор выветривания отмечаются зоны дезинтеграции и гидратации, а также зона гидролиза. Зона гидролиза исходных пород представлена глинами каолинит-гидрослюдистого состава. Глины преимущественно бесструктурные, участками со слабо выраженной реликтовой сланцеватостью. Мощность линейных кор выветривания составляет около 30 м.

В результате эрозии остаточных кор выветривания и плоскостного делювиального смыва происходит переотложение остаточных кор выветривания в виде аллювиально-пролювиальных отложений. Продукты переотложения остаточных кор выветривания представлены пестрыми бесструктурными глинами. Наибольшие содержания золота приурочены именно к переотложенной коре выветривания и зоне гидролиза остаточной коры выветривания [34]. Среди спутников золота установлены минералы группы карбонатов, сульфидов, фосфатов, окислов титана.

\section{Материалы и методы исследования}

Исходным материалом для исследования минералов послужили концентраты керновых и групповых проб весом 1-80 кг из керна скважин Колбихинской площади (рис. 1, c).

Минеральный и химический состав исследуемых проб изучался с использованием классического минералогического анализа, рентгено-флуоресцентного анализа (РФА) и сканирующей электронной микроскопии (СЭМ).

Минералогический анализ проведен по следующей методике: дробление исходной породы, двукратное обогащение на центробежном концентраторе Пугачева, рассев на фракции по размерности на ситах 1; 0,5; 0,25; 0,1 мм. Далее выделение тяжелой фракции минералов в бромоформе, разделение тяжелой фракции на неэлектромагнитную и электромагнитную 
фракции, изучение минерального состава под бинокуляром Olympus SZX. РФА выполнялся с использованием микроанализатора HORIBA X-Ray Analytical Microscope XGT 7200, оснащенного энергодисперсионным детектором с пространственным разрешением до 10 мкм. СЭМ проводился с использованием микроскопа TESCAN VEGA 3 SBU с энергодисперсионной приставкой фирмы Oxford X-Max 50. Ускоряющее напряжение для СЭМ съемки и анализа было 20 кВ с интенсивностью тока зонда в пределах 4-15 нА.

\section{Результаты}

В корах выветривания Томского района установлены: 1) фосфаты группы апатита; 2) ортофосфаты редкоземельных элементов и тория; 3) алюмофосфаты группы крандаллита. По генетическому признаку фосфатные минералы разделены на группы: а) первичные терригенные фосфаты, устойчивые в корах выветривания и выделившиеся при разрушении коренных пород (монацит, ксенотим, апатит); б) преобразованные, измененные в процессе выветривания (монацит); в) новообразованные, образованные в процессе формирования кор выветривания (монацит, куларит, флоренсит, крандаллит, гояцит, горсейксит, плюмбогуммит).

Anатит отмечается во всех частях разреза коры выветривания и по происхождению является первичным обломочным.
В зонах гидратации и гидролиза минерал присутствует в виде мелких, размером менее 0,1...0,05 мм, бесцветных прозрачных хорошо ограненных кристаллов гексагональной призмы, трещиноватых обломков удлиненной и неправильной формы, в виде включений в кубических кристаллах пирита со ступенчатым ростом граней, в окатанном цирконе и обломках магматических пород. Совместно с апатитом в кристаллах пирита встречаются удлиненные чешуйки гидрослюд, игольчатые кристаллы рутила, удлиненные зерна плагиоклаза. В магматических породах апатит встречается совместно с кварцем, калиевым полевым шпатом, хлоритом, сфеном, карбонатом, пироксеном и цирконом (рис. 2, $a-d)$.

Кристаллохимические формулы апатита:

a) из зоны дезинтеграции:

1) $\mathrm{Ca}_{10.14}\left[\mathrm{P}_{6.32} \mathrm{O}_{26.00}\right]\left(\mathrm{F}_{?}\right)$;

2) $\mathrm{Ca}_{10.09}\left[\mathrm{P}_{6.20} \mathrm{Si}_{0.14} \mathrm{O}_{25.91}\right]\left(\mathrm{F}_{?} \mathrm{Cl}_{0.09}\right)$.

б) из зоны гидратации:

1) $\mathrm{Ca}_{9.17}\left[\mathrm{P}_{5.74} \mathrm{~S}_{0.22} \mathrm{Si}_{0.19} \mathrm{O}_{23.75}\right]\left(\mathrm{F}_{2.25}\right)$;

2) $\mathrm{Ca}_{9.25}\left[\mathrm{P}_{5.493} \mathrm{Si}_{0.20} \mathrm{~S}_{0.09} \mathrm{O}_{23.72}\right]\left(\mathrm{F}_{2.28}\right)$.

в) из зоны гидролиза:

1) $\mathrm{Ca}_{9.75}\left[\mathrm{P}_{6.09} \mathrm{O}_{24.25}\right]\left(\mathrm{F}_{1.75}\right)$

2) $\mathrm{Ca}_{9.68}\left[\mathrm{P}_{6.11} \mathrm{O}_{24.11}\right]\left(\mathrm{F}_{1.89}\right)$;

3) $\mathrm{Ca}_{8.96}\left[\mathrm{P}_{5.79} \mathrm{Si}_{0.38} \mathrm{~S}_{0.10} \mathrm{O}_{23.98}\right]\left(\mathrm{F}_{2.02}\right)$;

4) $\mathrm{Ca}_{8.86}\left[\mathrm{P}_{5.63} \mathrm{Si}_{0.84} \mathrm{O}_{23.68}\right]\left(\mathrm{F}_{2.32}\right)$.
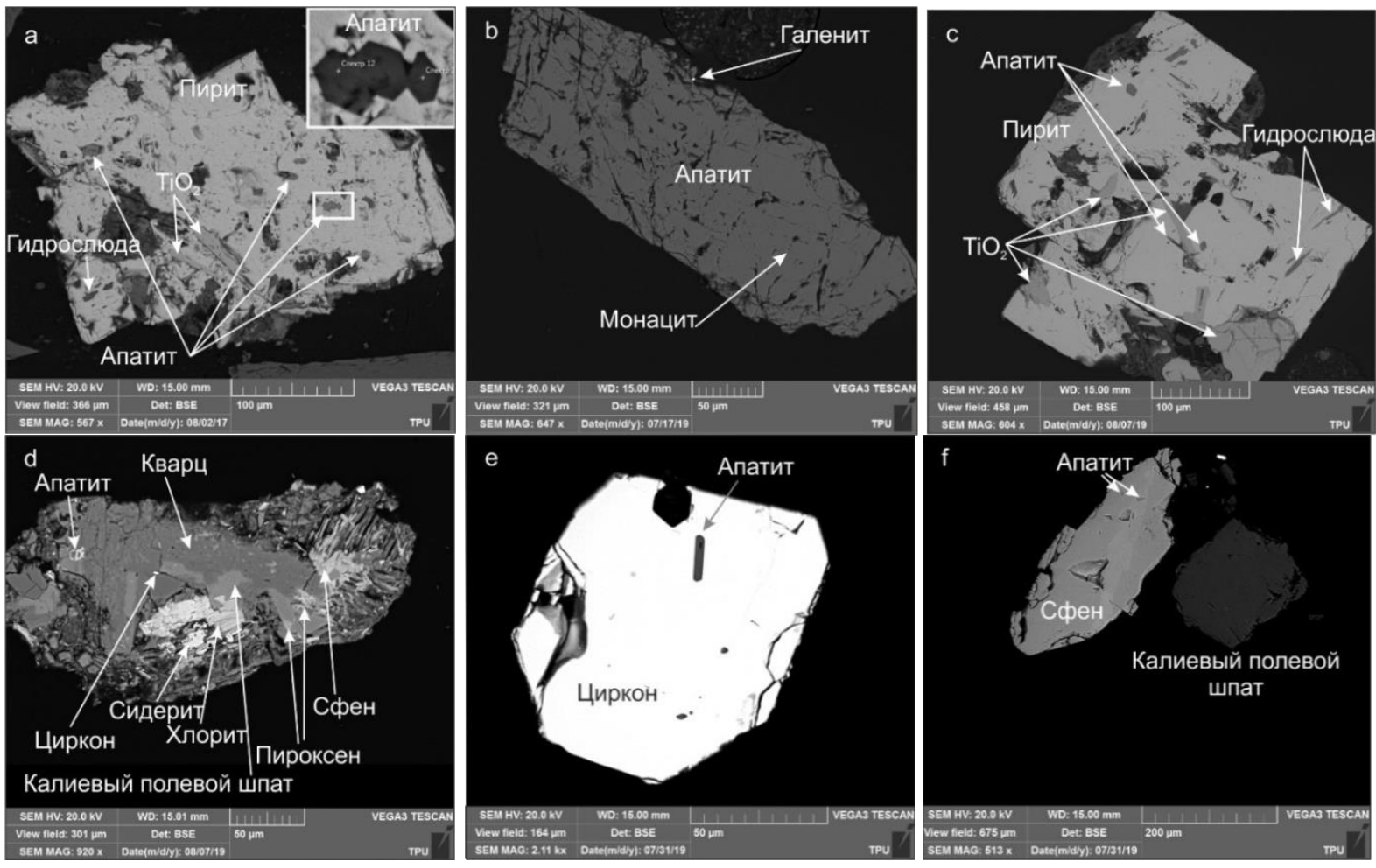

Рис. 2. Морфология и парагенетические ассочиации апатита: включения гексагональных призм апатита в кубических кристаллах пирита (a, c), в обломке магматической породы (d), в цииконе (e), сфене (f); интенсивно трещиноватый призматический кристалл апатита с микроскопическими включениями монацита и галенита (b) (зона гидратации (a, b), зона гидролиза (c, d) ОКВ, ПКВ (e, f))

Fig. 2. Morphology and paragenetic associations of apatite: inclusions of hexagonal prisms of apatite in cubic pyrite crystals $(a, c)$, in a fragment of igneous rock $(d)$, in zircon $(e)$, sphene $(f)$; intensely fractured prismatic apatite crystal with microscopic inclusions of monazite and galena $(b)$ (hydration zone $(a, b)$, hydrolysis zone $(c, d)$ residual weathering crust, redeposited weathering crust $(e, f)$ ) 
В переотложенной коре выветривания апатит встречается в виде единичных окатанных обломков изометричной или удлиненной формы размером до 0,5 мм, включений призматических кристаллов и неправильных зерен размером менее 0,02-0,01 мм в кубических кристаллах пирита, обломках дайки, сфене, цирконе (рис. 2, $e, f)$.

Кристаллохимические формулы апатита переотложенной коры выветривания:

1) $\left(\mathrm{Ca}_{9.71} \mathrm{Mn}_{0.05} \mathrm{Sr}_{0.02}\right)_{9.78}\left[\mathrm{P}_{5.81} \mathrm{Si}_{0.16} \mathrm{~S}_{0.22} \mathrm{O}_{25.99}\right]\left(\mathrm{F}_{?} \mathrm{Cl}_{0.01}\right)$;

2) $\mathrm{Ca}_{9.41}\left[\mathrm{P}_{6.03} \mathrm{Si}_{0.18} \mathrm{O}_{24.09}\right]\left(\mathrm{F}_{1.91}\right)$;

3) $\mathrm{Ca}_{9.50}\left[\mathrm{P}_{5.94} \mathrm{O}_{24.22}\right]\left(\mathrm{F}_{1.78}\right)$;

4) $\mathrm{Ca}_{9.45}\left[\mathrm{P}_{5.97} \mathrm{Si}_{0.10} \mathrm{~S}_{0.08} \mathrm{O}_{24.10}\right]\left(\mathrm{F}_{1.90}\right)$;

5) $\mathrm{Ca}_{9.66}\left[\mathrm{P}_{6.05} \mathrm{Si}_{0.11} \mathrm{O}_{24.15}\right]\left(\mathrm{F}_{1.85}\right)$;

6) $\mathrm{Ca}_{9.04}\left[\mathrm{P}_{5.11} \mathrm{O}_{24.50}\right]\left(\mathrm{F}_{1.50}\right)$;

7) $\mathrm{Ca}_{9.10}\left[\mathrm{P}_{5.94} \mathrm{Si}_{0.59} \mathrm{O}_{24.28}\right]\left(\mathrm{F}_{1.68} \mathrm{Cl}_{0.04}\right)$;

8) $\mathrm{Ca}_{8.07}\left[\mathrm{P}_{5.51} \mathrm{Si}_{1.64} \mathrm{O}_{24.68}\right]\left(\mathrm{F}_{1.32}\right)$.
Bсе изученные апатиты по составу соответствуют фтор-апатитам с содержанием фтора 2,58-4,40\%. В единичных зернах минерала установлено незначительное содержание хлора (до 0,33 \%). В химическом составе наблюдаются некоторые вариации в средних содержаниях оксида кальция 51,48-53,82 \% и оксида фосфора 40,16-43,47 \%, значительное увеличение содержания $\mathrm{CaO}$ до 55,72 \% и $\mathrm{P}_{2} \mathrm{O}_{5}$ до 43,93 \% в апатитах зоны дезинтеграции обусловлено тем, что здесь не установлено содержание фтора (табл. 1). Также значительные расхождения в составе обусловлены примесями элементов, входящих в состав вмещающих апатит минералов - пирита, циркона, сфена. В зоне гидратации в единичных трещиноватых обломках апатита установлены микроскопические включения галенита размером менее 0,003 мм и монацита размером менее 0,001 мм, вследствие чего в составе апатита устанавливаются примеси церия и неодима.

Таблица 1. Химический состав апатита

Table 1. Chemical composition of apatite

\begin{tabular}{|c|c|c|c|c|c|c|c|c|c|}
\hline \multirow{2}{*}{$\begin{array}{l}\text { Зона коры } \\
\text { выветри- } \\
\text { вания } \\
\text { Weathering } \\
\text { crust zone }\end{array}$} & \multicolumn{5}{|c|}{$\begin{array}{l}\text { Остаточная кора выветривания } \\
\text { Residual weathering crust }\end{array}$} & \multirow{2}{*}{\multicolumn{4}{|c|}{$\begin{array}{l}\text { Переотложенная кора выветривания } \\
\text { Redeposited weathering crust }\end{array}$}} \\
\hline & $\begin{array}{l}\text { Зона дезинте- } \\
\text { грации } \\
\text { Disintegration } \\
\text { zone }\end{array}$ & \multicolumn{3}{|c|}{$\begin{array}{l}\text { Зона гидратации } \\
\text { Hydration zone }\end{array}$} & $\begin{array}{l}\text { Зона гид- } \\
\text { ролиза } \\
\text { Hydrolysis } \\
\text { zone }\end{array}$ & & & & \\
\hline \multirow[b]{2}{*}{ 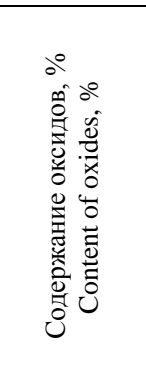 } & \multicolumn{9}{|c|}{ Морфология и ассоциация минералов/Morphology and association of minerals } \\
\hline & 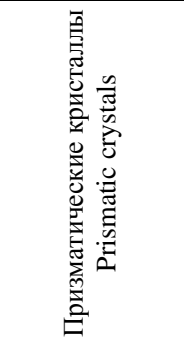 & 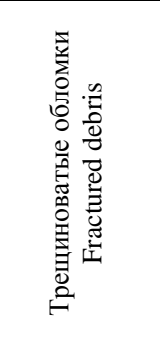 & 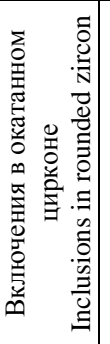 & 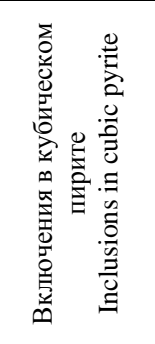 & 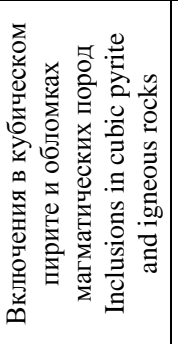 & 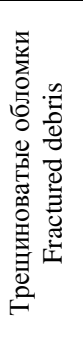 & 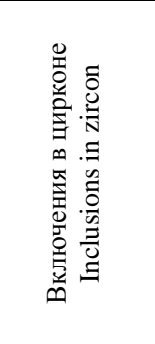 & 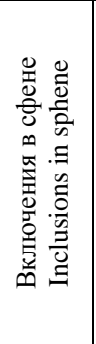 & 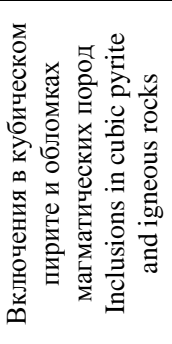 \\
\hline $\mathrm{CaO}$ & $\frac{55,38-55,72}{55,55}$ & $\frac{53,14-54,85}{53,82}$ & 52,89 & $\frac{50,46-52,52}{51,48}$ & $\frac{49,59-53,46}{51,51}$ & 53,02 & $\frac{46,46-51,00}{48,73}$ & 49,87 & $\frac{51,92-53,23}{52,40}$ \\
\hline $\mathrm{P}_{2} \mathrm{O}_{5}$ & $\frac{43,03-43,93}{43,48}$ & $\frac{40,39-42,66}{41,82}$ & 43,47 & $\frac{40,01-42,52}{41,50}$ & $\frac{39,87-42,53}{41,33}$ & 40,16 & $\frac{40,12-42,13}{41,13}$ & 35,69 & $\frac{41,52-42,23}{41,86}$ \\
\hline $\mathrm{F}$ & 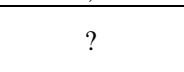 & $\frac{3,37-3,91}{3,65}$ & 3,51 & $\frac{3,70-4,26}{3,96}$ & $\frac{3,25-4,40}{3,74}$ & $?$ & $\frac{2,58-3,19}{2,88}$ & 2,81 & $\frac{3,33-3,57}{3,47}$ \\
\hline $\mathrm{Cl}$ & $\frac{0,00-0,33}{0,16}$ & - & 0,18 & - & - & 0,03 & $\frac{0,00-0,13}{0,07}$ & - & - \\
\hline $\mathrm{SO}_{3}$ & - & - & - & $\frac{0,00-1,74}{0,62}$ & $\frac{0,00-0,79}{0,20}$ & 1,68 & - & - & $\frac{0,00-1,54}{0,55}$ \\
\hline $\mathrm{FeO} / \mathrm{Fe}_{2} \mathrm{O}_{3}$ & $\frac{0,26-0,35}{0,31}$ & $\frac{0,00-1,72}{0,57}$ & - & $\frac{1,24-2,12}{1,68}$ & $\frac{0,00-1,96}{0,94}$ & 3,52 & - & - & $\frac{0,44-1,69}{1,16}$ \\
\hline $\mathrm{SiO}_{2}$ & $\frac{0,00-0,82}{0,41}$ & - & - & $\frac{0,00-1,20}{0,68}$ & $\frac{0,00-5,06}{1,84}$ & 0,94 & $\frac{3,55-10,11}{6,83}$ & 5,43 & $\frac{0,00-1,07}{0,57}$ \\
\hline $\mathrm{Al}_{2} \mathrm{O}_{3}$ & 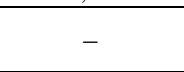 & - & - & 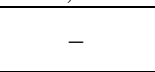 & $\frac{0,00-0,72}{0,33}$ & & $\frac{0,00-0,73}{0,37}$ & - & 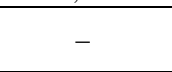 \\
\hline $\mathrm{K}_{2} \mathrm{O}$ & - & - & - & - & $\frac{0,00-0,50}{0,13}$ & & - & - & - \\
\hline $\mathrm{TiO}_{2}$ & $\frac{0,00-0,14}{0,07}$ & - & - & - &,- 10 & & - & 6,21 & - \\
\hline $\mathrm{SrO}$ & $\frac{0,00-0,02}{0,01}$ & - & - & - & - & 0,16 & - & - & - \\
\hline $\mathrm{As}_{2} \mathrm{O}_{5}$ & - & - & - & - & - & 0,01 & - & - & - \\
\hline $\mathrm{MnO}_{2}$ & - & - & - & - & - & 0,42 & - & - & - \\
\hline $\mathrm{MgO}$ & - & - & - & $\frac{0,00-0,35}{0,09}$ & - & & - & - & - \\
\hline $\mathrm{Ce}_{2} \mathrm{O}_{3}$ & - & $\frac{0,00-1,98}{0,66}$ & - & - & - & & - & - & - \\
\hline $\mathrm{Nd}_{2} \mathrm{O}_{3}$ & - & $\frac{0,00-2,76}{0,92}$ & - & - & - & & - & - & - \\
\hline
\end{tabular}



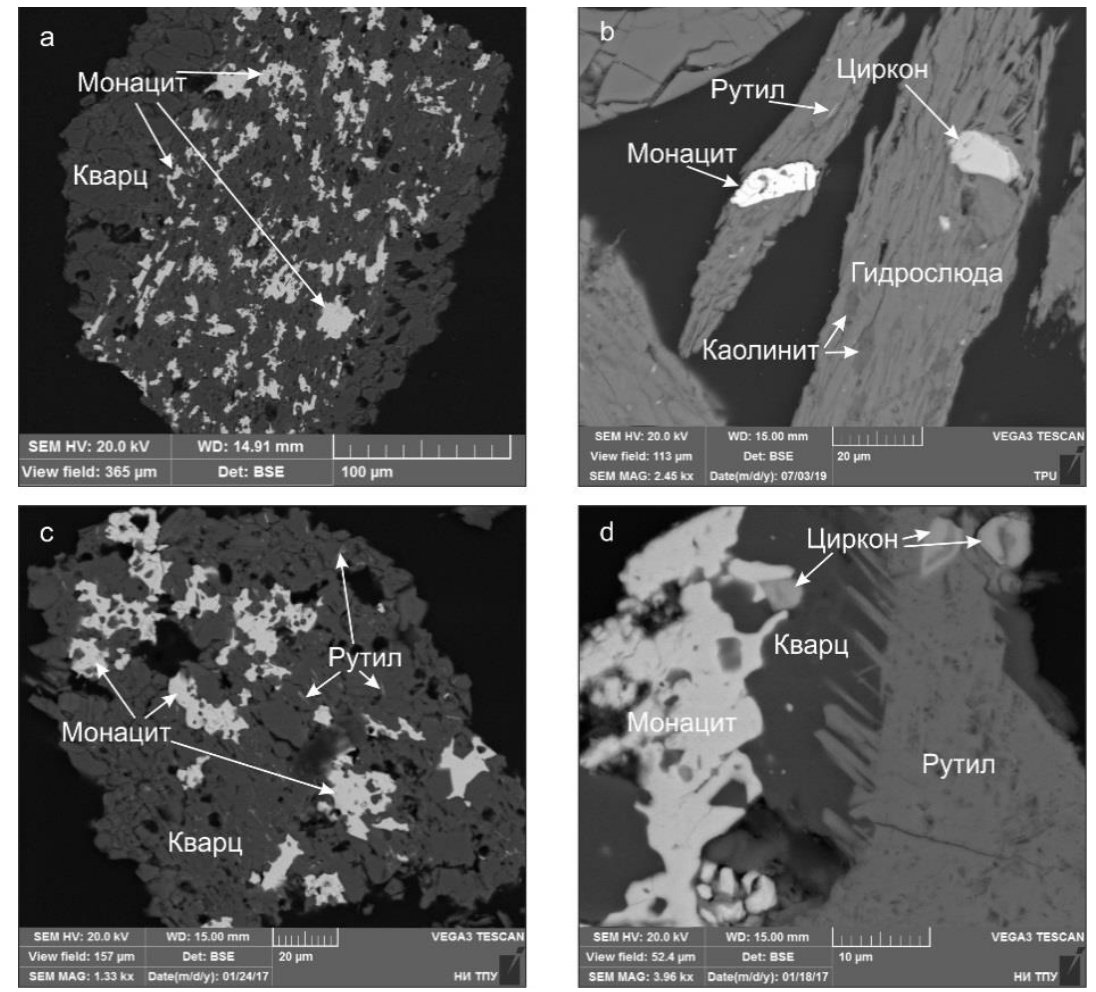

Рис. 3. Наиболее типичные формы выделений первичного монацита в зонах гидратации (a, b) и гидролиза (c, d)

Fig. 3. Most typical forms of primary monazite precipitation in the zones of hydration $(a, b)$ and hydrolysis $(c, d)$

Редкоземельные фосфаты в изучаемой коре выветривания представлены монацитом, куларитом и ксенотимом.

Монацит встречается по всему разрезу остаточной коры выветривания и представлен первичным, преобразованным и новообразованным типами.

Первичный обломочный моначит установлен в зонах гидратации и гидролиза ОКВ, минерал находится в ассоциации с кварцем, полевыми шпатами и гидрослюдами (рис. 3). Присутствует чаще в виде неправильных агрегатов размером 0,05-0,1 мм, реже в виде отдельных удлиненных и изометричных зерен, удлиненных призматических кристаллов размером до 0,02-0,03 мм. Минерал образует срастания с кварцем и полевым шпатом, в которых часто наблюдаются включения иголочек и неправильных зерен рутила, реже присутствует в виде включений в гидрослюдистых агрегатах, также установлены единичные включения - реликты зерен в сфалерите (рис. 4).

По химическому составу в зонах гидратации и гидролиза разновидности исходного терригенного монацита имеют существенно цериевый состав $\mathrm{Ce}>\mathrm{La} \geq \mathrm{Nd}$, осложненный примесями $\mathrm{Sm}, \mathrm{Th}, \mathrm{Gd}, \mathrm{Ca}$, $\mathrm{Si}$, иногда Y. Содержания элементов в химическом составе монацита разных зон сопоставимо, содержания церия в среднем по зонам составляют 31,43-32,16 \%, лантана $15,28-15,8 \%$, неодима $12,47-12,51 \%$, тория $2,34-2,77 \%$. В составе минерала могут присутствовать празеодим (до 4,23 \%) и средние лантаноиды самарий (до $3,03 \%$ ) и гадолиний (до 2,46 \%), а также иногда иттрий (до 1,77 \%). Суммарное количество редкоземельных элементов в минерале составляет
63,41-64,62 \%. В составе минерала наблюдаются примеси вмещающих минералов - кварца и слюд $\left(\mathrm{SiO}_{2}, \mathrm{Al}_{2} \mathrm{O}_{3}, \mathrm{~K}_{2} \mathrm{O}\right)$. Иногда присутствует примесь кальция (до 1,07 \%), которая может входить в состав катионной группы. В единичных случаях установлены примеси вольфрама (до 0,48 \%) и кадмия (до $0,80 \%$ ) (табл. 2).

Для мелких включений монацита размером до 5-10 мкм в сфалерите характерно снижение содержаний фосфора (до $28,07 \%$ ) и церия (до 27,94 \%), содержания лантана $(13,17 \%)$, неодима (11,20\%), празеодима $(2,96 \%)$, самария $(1,66 \%)$, гадолиния $(1,38 \%)$ и тория $(1,12 \%)$. Сoстав минерала загрязнен примесями вмещающего сфалерита (цинк, сера), также включений слюды (кремний, алюминий, калий). Формула минерала имеет вид $\left(\mathrm{Ce}_{0.37} \mathrm{La}_{0.18} \mathrm{Nd}_{0.15} \mathrm{Pr}_{0.04} \mathrm{Sm}_{0.02} \mathrm{Gd}_{0.02} \mathrm{Th}_{0.01}\right)_{0.79}\left[\mathrm{P}_{0.87} \mathrm{O}_{4}\right]$ (табл. 2$)$.

Преобразованный монацит встречается в зоне гидратации (рис. $2, b$, рис. 4). Минерал присутствует в виде мелких реликтовых включений размером менее 0,05 мм в апатите и совместном агрегате алюмофосфатов гояцита и горсейксита, в составе обнаруженного монацита наблюдаются примеси вмещающих минералов - кварца, слюд, алюмофосфатов $\left(\mathrm{SiO}_{2}, \mathrm{Al}_{2} \mathrm{O}_{3}\right.$, $\mathrm{K}_{2} \mathrm{O}$ ). По соотношению главных компонентов минерал имеет существенно цериевый состав $(27,14 \%)$, лантан (12,69 \%) преобладает над неодимом $(9,37 \%)$, наблюдается снижение содержания фосфора $(28,88 \%)$ и суммарного содержания легких лантаноидов $(49,20 \%)$ по сравнению с первичным монацитом. В составе минерала отсутствуют средние лантаноиды - самарий и гадолиний. Кристаллохимическая формула минерала имеет вид $\left(\mathrm{Ce}_{0.31} \mathrm{La}_{0.15} \mathrm{Nd}_{0.11}\right)_{0.57}\left[\mathrm{P}_{0.77} \mathrm{O}_{4}\right]$ (табл. 2). 
Таблица 2. Химический состав первичных и преобразованных монацитов ОКВ

Table 2. Chemical composition of primary and hypergene-transformed monazites of the residual weathering crust

\begin{tabular}{|c|c|c|c|c|}
\hline \multirow{2}{*}{$\begin{array}{l}\text { Зоны коры выветривания } \\
\text { Weathering crust zones }\end{array}$} & \multicolumn{4}{|c|}{ Остаточная кора выветривания/Residual weathering crust } \\
\hline & \multicolumn{3}{|c|}{$\begin{array}{c}\text { Зона гидратации } \\
\text { Hydration zone }\end{array}$} & $\begin{array}{l}\text { Зона гидролиза } \\
\text { Hydrolysis zone }\end{array}$ \\
\hline & \multicolumn{4}{|c|}{ Морфология и ассоциация минералов/Morphology and association of minerals } \\
\hline $\begin{array}{l}\text { Содержание оксидов, \% } \\
\text { Content of oxides, \% }\end{array}$ & $\begin{array}{c}\text { Первичный монацит } \\
\text { (включения в кварце и } \\
\text { гидрослюдах) } \\
\text { Primary monazite } \\
\text { (inclusions in quartz and } \\
\text { hydromica) } \\
\end{array}$ & $\begin{array}{l}\text { Первичный мона- } \\
\text { цит (включения в } \\
\text { сфалерите) } \\
\text { Primary monazite } \\
\text { (inclusions in } \\
\text { sphalerite) } \\
\end{array}$ & $\begin{array}{c}\text { Преобразованный монацит } \\
\text { (включения в гояцит- } \\
\text { горсейксите) } \\
\text { Transformed monazite } \\
\text { (inclusions in goyazite- } \\
\text { gorseixite) }\end{array}$ & $\begin{array}{c}\text { Первичный монацит } \\
\text { (включения в кварце и } \\
\text { гидрослюдах) } \\
\text { Primary monazite } \\
\text { (inclusions in quartz and } \\
\text { hydromica) } \\
\end{array}$ \\
\hline $\mathrm{P}_{2} \mathrm{O}_{5}$ & $\frac{29,71-33,94}{31,43}$ & 28,07 & 28,88 & $\frac{29,95-35,63}{32,16}$ \\
\hline $\mathrm{Ce}_{2} \mathrm{O}_{3}$ & $\frac{28,46-34,55}{31,94}$ & 27,94 & 27,14 & $\frac{29,28-33,02}{31,47}$ \\
\hline $\mathrm{La}_{2} \mathrm{O}_{3}$ & $\frac{13,63-17,45}{15,80}$ & 13,17 & 12,69 & $\frac{13,47-17,16}{15,28}$ \\
\hline $\mathrm{Nd}_{2} \mathrm{O}_{3}$ & $\frac{11,41-14,34}{12,51}$ & 11,20 & 9,37 & $\frac{11,39-13,29}{12,47}$ \\
\hline $\mathrm{Pr}_{2} \mathrm{O}_{3}$ & $\frac{0,00-4,23}{2,72}$ & 2,96 & - & $\frac{0,00-3,96}{2,31}$ \\
\hline $\begin{array}{c}\Sigma \text { Легких лантаноидов } \\
\Sigma \text { of light lanthanide }\end{array}$ & $\frac{57,28-66,77}{62,74}$ & 55,27 & 49,20 & $\frac{56,70-63,43}{61,53}$ \\
\hline $\mathrm{Sm}_{2} \mathrm{O}_{3}$ & $\frac{0,00-2,18}{1,44}$ & 1,66 & - & $\frac{0,00-3,03}{1,25}$ \\
\hline $\mathrm{Gd}_{2} \mathrm{O}_{3}$ & $\frac{0,00-1,49}{0,61}$ & 1,38 & - & $\frac{0,00-2,46}{0,64}$ \\
\hline $\begin{array}{l}\Sigma \text { Средних лантаноидов } \\
\Sigma \text { of media lanthanide }\end{array}$ & $\frac{0,00-3,67}{1,87}$ & 3,04 & - & $\frac{0,00-5,49}{1,89}$ \\
\hline ¿Р3Э & $\frac{60,56-69,87}{64,62}$ & 58,31 & 49,20 & $\frac{56,70-66,57}{63,41}$ \\
\hline $\mathrm{Y}_{2} \mathrm{O}_{3}$ & - & - & - & $\frac{0,00-1,77}{0,18}$ \\
\hline $\mathrm{ThO}_{2}$ & $\frac{0,91-3,99}{2,77}$ & 1,12 & - & $\frac{0,00-5,71}{2,34}$ \\
\hline $\mathrm{SiO}_{2}$ & $\frac{0,30-3,51}{1,04}$ & 2,76 & 10,29 & $\frac{0,00-2,00}{0,88}$ \\
\hline $\mathrm{Al}_{2} \mathrm{O}_{3}$ & $\frac{0,00-1,88}{0,20}$ & 1,78 & 9,79 & $\frac{0,00-0,91}{0,11}$ \\
\hline $\mathrm{CaO}$ & $\frac{0,00-0,80}{0,27}$ & 0,61 & - & $\frac{0,00-1,07}{0,40}$ \\
\hline $\mathrm{K}_{2} \mathrm{O}$ & $\frac{0,00-0,32}{0,03}$ & - & 1,84 & $\frac{0,00-0,58}{0,10}$ \\
\hline $\mathrm{SO}_{3}$ & - & 3,73 & - & $\frac{0,00-2,00}{0,25}$ \\
\hline $\mathrm{FeO}$ & - & - & - & $\frac{0,00-2,40}{0,30}$ \\
\hline $\mathrm{WO}_{3}$ & $\frac{0,00-0,48}{0,04}$ & - & - & - \\
\hline $\mathrm{CdO}$ & $\frac{0,00-0,80}{0,07}$ & - & - & - \\
\hline $\mathrm{ZnO}$ & - & 3,61 & - & - \\
\hline
\end{tabular}

В зоне гидролиза появляются новообразованные редкоземельные фосфаты - монацит и куларит, при этом первичный куларит в пробах не установлен (рис. 4). Сoдержание новообразованных фосфатов незначительно.

Монацит встречается в виде мелких включений неправильной формы размером до 0,02 мм в железистом карбонате - сидерите. Минерал имеет существенно цериевый состав, соотношение элементов соответствует $\mathrm{Ce}>\mathrm{La} \geq \mathrm{Nd}$, но приближается к $\mathrm{Ce}>\mathrm{Nd}$ $\geq \mathrm{La}$, в отличие от исходного монацита снижается содержание церия (менее $30 \%$ ), лантана (менее $15 \%$ ), тория (менее $2 \%$ ) и суммы редкоземельных элементов (менее $65 \%$ ) с уменьшением доли легких (до около $60 \%$ ), возрастает роль неодима (более $13 \%$ ) и доля средних лантаноидов (до около 4 \%) (табл. 3). Не- сколько возрастают средние содержания празеодима $(3,75 \%)$, самария $(2,65 \%)$, гадолиния $(1,41 \%)$.

Куларит находится в ассоциации с сидеритом и кварцем, присутствует в виде единичного кристалла с прямоугольным сечением размером менее 0,015 мм. Минерал имеет существенно цериевый состав, но содержание церия по сравнению с монацитом снижено до $22,73 \%$, содержание неодима $(17,47 \%)$ превосходит содержание лантана $(10,41 \%)$, соотношение элементов соответствует $\mathrm{Ce}>\mathrm{Nd} \geq \mathrm{La}$ (табл. 3). В состав минерала входит около 7 \% иттрия. Празеодим, самарий, гадолиний, торий отсутствуют. Иногда присутствует примесь кальция (до 4,88 \%), которая может входить в состав катионной группы минерала. В составе минерала установлена примесь кремния. 
Таблица 3. Химический состав новообразованных монацита и куларита в ОКВ

Table 3. Chemical composition of newly formed monazite and cularite in the residual weathering crust

\begin{tabular}{|c|c|c|}
\hline \multirow{2}{*}{$\begin{array}{l}\text { Зона коры выветривания } \\
\text { Weathering crust zone }\end{array}$} & \multicolumn{2}{|c|}{ Остаточная кора выветривания/Residual weathering crust } \\
\hline & \multicolumn{2}{|c|}{ Зона гидролиза/Hydrolysis zone } \\
\hline \multirow{2}{*}{$\begin{array}{l}\text { Содержание оксидов, \% } \\
\text { Content of oxides, } \%\end{array}$} & \multicolumn{2}{|c|}{ Морфология и ассоциация минералов/Morphology and association of minerals } \\
\hline & $\begin{array}{l}\text { Гипергенный монацит (включения в сидерите) } \\
\text { Hypergenic monazite (inclusions in siderite) }\end{array}$ & $\begin{array}{c}\text { Гипергенный куларит (включения в кварце с сидеритом) } \\
\text { Hypergenic kularite (inclusions in quartz with siderite) }\end{array}$ \\
\hline $\mathrm{P}_{2} \mathrm{O}_{5}$ & $\frac{29,21-29,96}{29,69}$ & 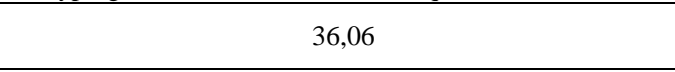 \\
\hline $\mathrm{Ce}_{2} \mathrm{O}_{3}$ & $\frac{29,03-29,22}{29,15}$ & 22,73 \\
\hline $\mathrm{La}_{2} \mathrm{O}_{3}$ & $\frac{13,66-14,57}{14,14}$ & 10,41 \\
\hline $\mathrm{Nd}_{2} \mathrm{O}_{3}$ & $\frac{13,09-13,53}{13,28}$ & 17,47 \\
\hline $\mathrm{Pr}_{2} \mathrm{O}_{3}$ & $\frac{3,53-4,08}{3,75}$ & - \\
\hline $\begin{array}{c}\Sigma \text { Легких лантаноидов } \\
\Sigma \text { of light lanthanide }\end{array}$ & $\frac{60,16-60,66}{60,33}$ & 50,61 \\
\hline $\mathrm{Sm}_{2} \mathrm{O}_{3}$ & $\frac{2,58-2,72}{2,65}$ & - \\
\hline $\mathrm{Gd}_{2} \mathrm{O}_{3}$ & $\frac{1,35-1,46}{1,41}$ & - \\
\hline $\begin{array}{c}\Sigma \text { Средних лантаноидов } \\
\Sigma \text { of media lanthanide }\end{array}$ & $\frac{3,93-4,14}{4,06}$ & - \\
\hline$\Sigma$ Р3Э & $\frac{64,10-64,77}{64,39}$ & 50,61 \\
\hline $\mathrm{Y}_{2} \mathrm{O}_{3}$ & - & 7,16 \\
\hline $\mathrm{ThO}_{2}$ & $\frac{0,00-1,89}{0,63}$ & - \\
\hline $\mathrm{SiO}_{2}$ & $\frac{0,69-0,85}{0,75}$ & 1,27 \\
\hline $\mathrm{CaO}$ & $\frac{0,36-0,51}{0,42}$ & 4,88 \\
\hline $\mathrm{FeO}$ & $\frac{2,17-2,55}{2,30}$ & - \\
\hline $\mathrm{As}_{2} \mathrm{O}_{5}$ & $\frac{0,00-2,86}{1,81}$ & - \\
\hline
\end{tabular}

Кристаллохимические формулы новобразованных монацита (1-3) и куларита (4) зоны гидролиза ОКВ:

1) $\left(\mathrm{Ce}_{0.41} \mathrm{La}_{0.21} \mathrm{Nd}_{0.19} \mathrm{Pr}_{0.04} \mathrm{Sm}_{0.04} \mathrm{Th}_{0.02} \mathrm{Gd}_{0.02} \mathrm{Ca}_{0.02}\right)_{0.95}\left[\mathrm{P}_{0.98} \mathrm{O}_{4}\right]$;

2) $\left(\mathrm{Ce}_{0.42} \mathrm{La}_{0.20} \mathrm{Nd}_{0.18} \mathrm{Pr}_{0.06} \mathrm{Sm}_{0.03} \mathrm{Gd}_{0.02} \mathrm{Ca}_{0.02}\right)_{0.93}\left[\mathrm{P}_{0.98} \mathrm{O}_{4}\right]$;

3) $\left(\mathrm{Ce}_{0.41} \mathrm{La}_{0.20} \mathrm{Nd}_{0.18} \mathrm{Pr}_{0.05} \mathrm{Sm}_{0.04} \mathrm{Gd}_{0.02} \mathrm{Ca}_{0.01}\right)_{0.91}\left[\mathrm{P}_{0.95} \mathrm{O}_{4}\right]$.

4) $\left(\mathrm{Ce}_{0.28} \mathrm{Nd}_{0.21} \mathrm{Ca}_{0.18} \mathrm{La}_{0.13} \mathrm{Y}_{0.13}\right)_{0.90}\left[\mathrm{P}_{1.04} \mathrm{O}_{4}\right]$;

В переотложенной коре выветривания монацит представлен первичным и преобразованным типами.

В переотложенной коре выветривания для терригенных монацитов характерны широкие вариации состава, возможно, свидетельствующие о различных источниках его переотложения.

Первичный обломочный монацит встречается в виде неправильных агрегатов размером менее 0,1 мм в срастании с кварцем и рутилом, реже присутствует в виде единичных самостоятельных в различной степени окатанных трещиноватых зерен неправильной формы размером до 0,1-0,4 мм желтоватого, светлобурого цвета (рис. 4).

По химическому составу минерал незначительно отличается от первичных монацитов зон гидратации и гидролиза остаточной коры выветривания. Средние содержания элементов составляют: церия $31,69-31,81 \%$, лантана - 15,21-15,62 \%, неодима 11,18-12,45 \%, в составе минерала может присутствовать празеодим (до 3,85\%). В отдельных зернах присутствует иттрий (до $2,87 \%$ ) и торий (до
$12,85 \%$, средние содержания 2,47-4,52 \%), суммарное количество редкоземельных элементов составляет 63,44-64,05\%.

Кристаллохимические формулы первичного монацита переотложенной коры выветривания:

1) $\left(\mathrm{Ce}_{0.41} \mathrm{La}_{0.21} \mathrm{Nd}_{0.17} \mathrm{Pr}_{0.04} \mathrm{Sm}_{0.02} \mathrm{Gd}_{0.01} \mathrm{Th}_{0.01}\right)_{0.86}\left[\mathrm{P}_{0.96} \mathrm{O}_{4}\right]$;

2) $\left(\mathrm{Ce}_{0.42} \mathrm{La}_{0.21} \mathrm{Nd}_{0.13} \mathrm{Th}_{0.11} \mathrm{Pr}_{0.02} \mathrm{Sm}_{0.01} \mathrm{Y}_{0.01}\right)_{0.91}\left[\mathrm{P}_{0.92} \mathrm{O}_{4}\right]$;

3) $\left(\mathrm{Ce}_{0.45} \mathrm{La}_{0.26} \mathrm{Nd}_{0.14} \mathrm{Pr}_{0.04} \mathrm{Sm}_{0.02} \mathrm{Gd}_{0.01}\right)_{0.92}\left[\mathrm{P}_{1.01} \mathrm{O}_{4}\right]$;

4) $\left(\mathrm{Ce}_{0.47} \mathrm{La}_{0.20} \mathrm{Nd}_{0.18} \mathrm{Pr}_{0.05} \mathrm{Sm}_{0.03} \mathrm{Th}_{0.01}\right)_{0.94}\left[\mathrm{P}_{1.03} \mathrm{O}_{4}\right]$;

5) $\left(\mathrm{Ce}_{0.38} \mathrm{La}_{0.16} \mathrm{Nd}_{0.15} \mathrm{Pr}_{0.05} \mathrm{Sm}_{0.03} \mathrm{Th}_{0.03} \mathrm{Gd}_{0.02} \mathrm{Ca}_{0.02}\right)_{0.84}\left[\mathrm{P}_{0.95} \mathrm{O}_{4}\right]$;

6) $\left(\mathrm{Ce}_{0.45} \mathrm{La}_{0.18} \mathrm{Nd}_{0.14} \mathrm{Th}_{0.10} \mathrm{Ca}_{0.05}\right)_{0.92}\left[\mathrm{P}_{1.00} \mathrm{O}_{4}\right]$;

7) $\left(\mathrm{Ce}_{0.44} \mathrm{La}_{0.21} \mathrm{Nd}_{0.17} \mathrm{Pr}_{0.05} \mathrm{Sm}_{0.03} \mathrm{Th}_{0.03} \mathrm{Gd}_{0.01}\right)_{0.94}\left[\mathrm{P}_{1.01} \mathrm{O}_{4}\right]$;

8) $\left(\mathrm{Ce}_{0.38} \mathrm{La}_{0.19} \mathrm{Nd}_{0.15} \mathrm{Y}_{0.06} \mathrm{Pr}_{0.04} \mathrm{Th}_{0.04} \mathrm{Sm}_{0.03} \mathrm{Ca}_{0.03} \mathrm{Gd}_{0.02}\right)_{0.94}\left[\mathrm{P}_{1.01} \mathrm{O}_{4}\right]$;

9) $\left(\mathrm{Ce}_{0.41} \mathrm{La}_{0.21} \mathrm{Nd}_{0.17} \mathrm{Pr}_{0.04} \mathrm{Sm}_{0.02} \mathrm{Gd}_{0.02} \mathrm{Ca}_{0.02} \mathrm{Th}_{0.01}\right)_{0.86}\left[\mathrm{P}_{0.96} \mathrm{O}_{4}\right]$;

10) $\left(\mathrm{Ce}_{0.46} \mathrm{La}_{0.22} \mathrm{Nd}_{0.17} \mathrm{Pr}_{0.05} \mathrm{Sm}_{0.03} \mathrm{Th}_{0.01} \mathrm{Gd}_{0.01}\right)_{0.95}\left[\mathrm{P}_{1.02} \mathrm{O}_{4}\right]$;

11) $\left(\mathrm{Ce}_{0.46} \mathrm{La}_{0.23} \mathrm{Nd}_{0.16} \mathrm{Th}_{0.02}\right)_{0.87}\left[\mathrm{P}_{1.05} \mathrm{O}_{4}\right]$;

12) $\left(\mathrm{Ce}_{0.43} \mathrm{La}_{0.22} \mathrm{Nd}_{0.16}\right)_{0.81}\left[\mathrm{P}_{1.01} \mathrm{O}_{4}\right]$;

13) $\left(\mathrm{Ce}_{0.43} \mathrm{La}_{0.22} \mathrm{Nd}_{0.16} \mathrm{Pr}_{0.05} \mathrm{Sm}_{0.03} \mathrm{Th}_{0.03} \mathrm{Ca}_{0.01}\right)_{0.93}\left[\mathrm{P}_{0.99} \mathrm{O}_{4}\right]$;

14) $\left(\mathrm{Ce}_{0.45} \mathrm{La}_{0.23} \mathrm{Nd}_{0.18} \mathrm{Pr}_{0.05} \mathrm{Sm}_{0.03}\right)_{0.94}\left[\mathrm{P}_{1.02} \mathrm{O}_{4}\right]$;

15) $\left(\mathrm{Ce}_{0.45} \mathrm{La}_{0.21} \mathrm{Nd}_{0.19} \mathrm{Pr}_{0.04} \mathrm{Sm}_{0.04} \mathrm{Gd}_{0.01} \mathrm{Th}_{0.01}\right)_{0.95}\left[\mathrm{P}_{1.02} \mathrm{O}_{4}\right]$;

16) $\left(\mathrm{Ce}_{0.46} \mathrm{La}_{0.23} \mathrm{Nd}_{0.18} \mathrm{Pr}_{0.05} \mathrm{Sm}_{0.04} \mathrm{Gd}_{0.02}\right)_{0.98}\left[\mathrm{P}_{1.01} \mathrm{O}_{4}\right]$;

17) $\left(\mathrm{Ce}_{0.48} \mathrm{La}_{0.25} \mathrm{Nd}_{0.19}\right)_{0.92}\left[\mathrm{P}_{1.05} \mathrm{O}_{4}\right]$.

Преобразованный монациит в переотложенной коре выветривания встречается в срастаниях с кварцем, в совместном агрегате минералов образуют вростки новообразованные удлиненные кристаллы рутила. Размер агрегатов минерала неправильной формы не 
превышает 0,02 мм. По соотношению главных компонентов минерал имеет существенно цериевый состав $(32,98 \%)$, лантан $(18,71 \%)$ преобладает над неодимом $(9,67 \%)$, содержание празеодима составляет около $3 \%$, несколько снижено содержание фосфора $(29,21 \%)$, суммарное содержание легких лантаноидов не превышает 65 \%. В составе минерала присутствует небольшое количество средних лантаноидов, представленных самарием (1,25\%), а также торий $(2,4$ \%). В составе минерала наблюдаются примеси вмещающих минералов - кварца $\left(\mathrm{SiO}_{2}\right)$, примесь кальция может входить в состав катионной группы, замещая редкоземельные элементы, примесь серы может входить в состав анионной группы. Кристаллохимическая формула минерала имеет вид $\left(\mathrm{Ce}_{0.46} \mathrm{La}_{0.27} \mathrm{Nd}_{0.13} \mathrm{Pr}_{0.04} \mathrm{Ca}_{0.03} \mathrm{Sm}_{0.02} \mathrm{Th}_{0.02}\right)_{0.98}\left[\mathrm{P}_{0.95} \mathrm{~S}_{0.04} \mathrm{O}_{4}\right]$.

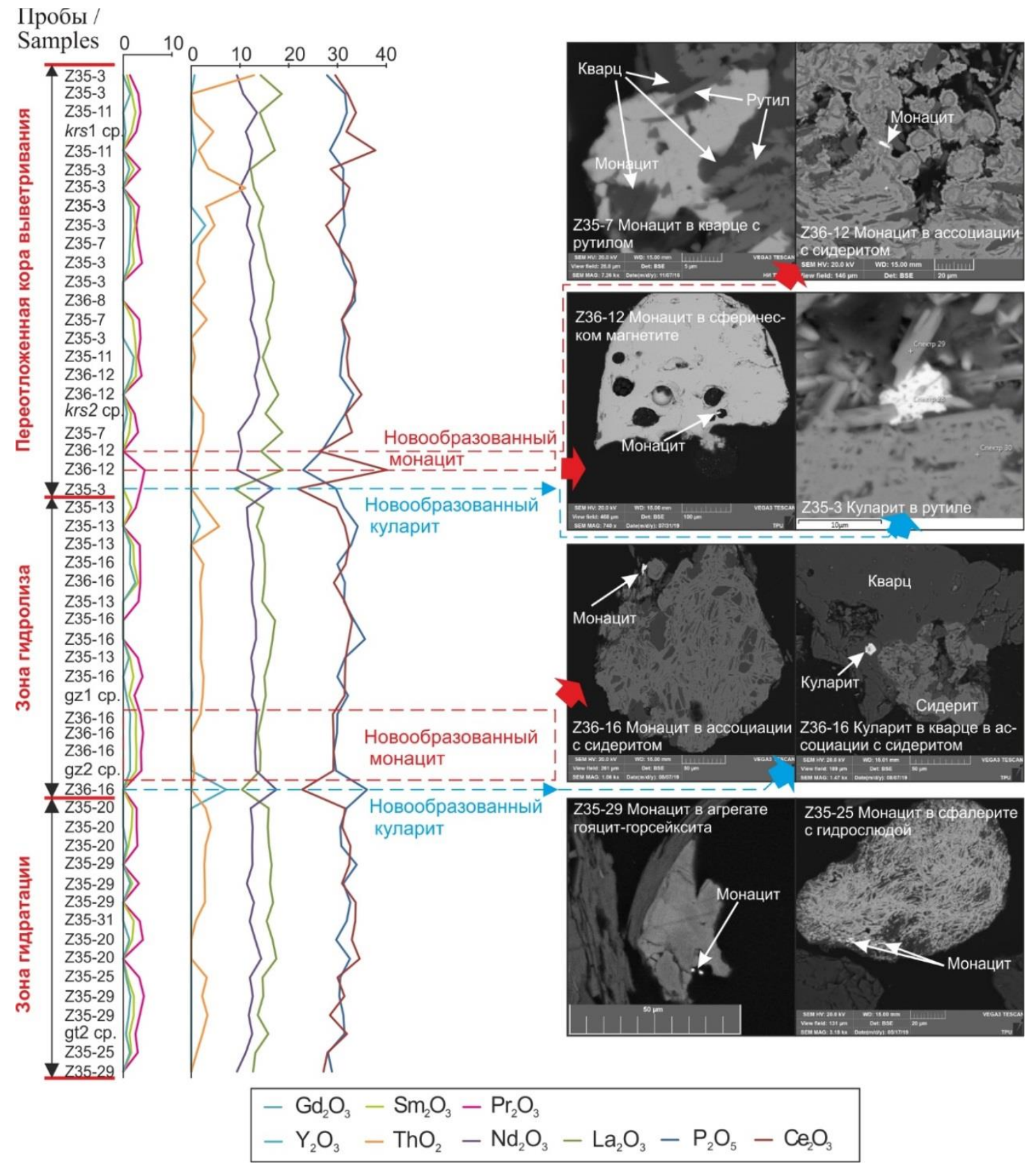

Рис. 4. Графики распределения основных компонентов, морфология и парагенетические ассочиации первичного обломочного, преобразованного монацита и новообразованных монацита и куларита

Fig. 4. Plots of distribution of the main components, morphology and paragenetic associations of primary clastic, transformed monazite and newly formed monazite and kularite

В переотложенной коре выветривания установлены новообразованные редкоземельные фосфаты - монацит и куларит.

Монаичт здесь встречается в виде мелких удлиненных включений неправильной формы размером до
0,01 мм в сидерите и сферическом магнетите. Монациты имеют сильно различающийся состав. Состав монацита из сидерита сходен по соотношению элементов с таковым из зоны гидролиза, но характеризуется снижением содержаний вследствие значительной 
примеси в составе вмещающего его сидерита (до 2,95 \% кальция, до 18,06 \% железа). Монацит, обнаруженный в магнетите, характеризуется значительным снижением содержания фосфора (до $23 \%$ ), неодима (до 9,41\%), резким возрастанием содержания церия (до 40 \%), высоким содержанием лантана (18,78\%) и празеодима $(4,37 \%)$. Несмотря на то, что в составе отсутствуют средние лантаноиды, суммарное содержание редкоземельных элементов составляет около $73 \%$. Также в составе минерала присутствуют примеси железа (4 \%) и кальция $(0,4 \%)$.

Куларит присутствует в виде микроскопического включения в рутиле, размер установленного включения неправильной формы не превышает 0,01 мм. Минерал имеет существенно цериевый состав и сходен с таковым из зоны гидролиза, содержание церия по сравнению с монацитом снижено до 21,82 \%, содержание неодима $(16,78 \%$ п) превосходит содержание лантана $(8,88 \%)$, соотношение элементов соответствует $\mathrm{Ce}>\mathrm{Nd} \geq \mathrm{La}$. Содержание празеодима составля- ет 3,57\%. Минерал содержит в своем составе свинец, возможно, за счет мелких включений галенита или его разрушения. В составе минерала отсутствуют иттрий, самарий, гадолиний, торий. Из примесей в составе минерала установлены титан, кремний, алюминий, кальций.

Кристаллохимические формулы новообразованного монацита $(1,2)$ и куларита $(3)$ переотложенной коры выветривания:

1) $\left(\mathrm{Ce}_{0.37} \mathrm{La}_{0.20} \mathrm{Nd}_{0.14} \mathrm{Th}_{0.01}\right)_{0.72}\left[\mathrm{P}_{0.88} \mathrm{O}_{4}\right]$;

2) $\left(\mathrm{Ce}_{0.64} \mathrm{La}_{0.30} \mathrm{Nd}_{0.15} \mathrm{Pr}_{0.07} \mathrm{Ca}_{0.02}\right)_{1.18}\left[\mathrm{P}_{0.84} \mathrm{O}_{4}\right]$;

3) $\left(\mathrm{Ce}_{0.27} \mathrm{Nd}_{0.20} \mathrm{La}_{0.11} \mathrm{Ca}_{0.10} \mathrm{Pr}_{0.04} \mathrm{~Pb}_{0.02}\right)_{0.44}\left[\mathrm{P}_{0.94} \mathrm{O}_{4}\right]$.

Ксенотим распространен в остаточной и переотложенной корах выветривания и представлен первичным обломочным типом. Минерал встречается в виде агрегатных скоплений размером до 0,05-0,06 мм и единичных изометричных трещиноватых зерен и кристаллов бледно-желтой, бесцветной окраски размером до 0,25 мм в ассоциации с кварцем и гидрослюдами (рис. 5).
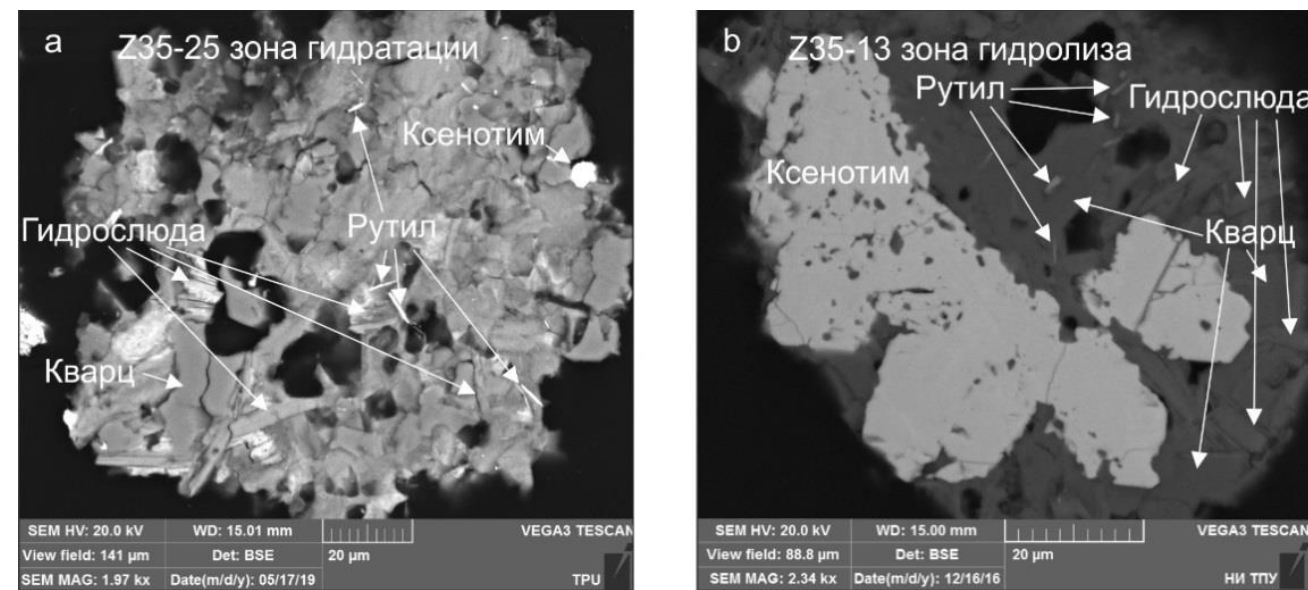

Pис. 5. Морфология и парагенетические ассочиачии ксенотима: мелкое изометричное включение (a) и агрегат (b) ксенотима в срастании с кварием и гидрослюдой (зона гидратации (a), зона гидролиза (b) ОКВ)

Fig. 5. Morphology and paragenetic associations of xenotime: small isometric inclusion (a) and aggregate $(b)$ of xenotime in intergrowth with quartz and hydromica (hydration zone (a), hydrolysis zone (b) residual weathering crust)

В химическом составе ксенотима наблюдаются вариации в содержании фосфора $(29,41-42,96 \%)$. Среднее содержание суммы тяжелых лантаноидов составляет 3,26-9,95 \%, с содержанием иттрия $37,18-48,60 \%$, эрбия 2,90-5,17\%. Иттербий в составе минерала присутствует не всегда (до 4,85 \%), в единичных зернах ксенотима из зоны дезинтеграции присутствует лутеций. Среднее содержание суммы средних лантаноидов составляет 9,09-11,41 \%, с содержанием диспрозия $5,34-9,90 \%$, гадолиния 3,00-7,45 \%. В зоне гидролиза в минерале обнаружены гольмий, европий, галлий. В зонах дезинтеграции и гидратации в минерале встречается незначительное количество тория. Из примесей в составе минерала установлены кремний, титан, стронций, кальций, железо, цирконий, обуславливающие колебания в содержаниях основных компонентов.

Кристалоохимические формулы ксенотима:

а) из зоны дезинтеграции:

1) $\left(\mathrm{Y}_{0.75} \mathrm{Dy}_{0.09} \mathrm{Er}_{0.05} \mathrm{Gd}_{0.04} \mathrm{Yb}_{0.03}\right)_{0.96}\left[\mathrm{P}_{1.01} \mathrm{O}_{4}\right]$;
2) $\quad\left(\mathrm{Y}_{0.76} \mathrm{Dy}_{0.07} \mathrm{Er}_{0.04} \mathrm{Gd}_{0.04} \mathrm{Yb}_{0.03}\right)_{0.94}\left[\mathrm{P}_{1.00} \mathrm{O}_{4}\right]$;

3) $\quad\left(\mathrm{Y}_{0.80} \mathrm{Gd}_{0.09} \mathrm{Dy}_{0.07} \mathrm{Er}_{0.05} \mathrm{Yb}_{0.04}\right)_{1.05}\left[\mathrm{P}_{0.94} \mathrm{O}_{4}\right]$;

4) $\left(\mathrm{Y}_{0.72} \mathrm{Dy}_{0.06} \mathrm{Er}_{0.04} \mathrm{Gd}_{0.03} \mathrm{Yb}_{0.02}\right)_{0.87}\left[\mathrm{P}_{0.98} \mathrm{O}_{4}\right]$.

б) из зоны гидратации:

1) $\left(\mathrm{Y}_{0.84} \mathrm{Dy}_{0.08} \mathrm{Gd}_{0.05} \mathrm{Er}_{0.04} \mathrm{Yb}_{0.01}\right)_{1.02}\left[\mathrm{P}_{0.94} \mathrm{O}_{4}\right]$;

2) $\left(\mathrm{Y}_{0.78} \mathrm{Dy}_{0.05} \mathrm{Er}_{0.03} \mathrm{Gd}_{0.03}\right)_{0.89}\left[\mathrm{P}_{1.00} \mathrm{O}_{4}\right]$.

в) из зоны гидролиза:

1) $\left(\mathrm{Y}_{0.82} \mathrm{Dy}_{0.07} \mathrm{Ho}_{0.13} \mathrm{Er}_{0.03} \mathrm{Yb}_{0.02} \mathrm{Gd}_{0.03}\right)_{1.10}\left[\mathrm{P}_{1.01} \mathrm{O}_{4}\right]$;

2) $\left(\mathrm{Y}_{0.82} \mathrm{Dy}_{0.06} \mathrm{Er}_{0.03} \mathrm{Gd}_{0.04}\right)_{0.95}\left[\mathrm{P}_{1.03} \mathrm{O}_{4}\right]$;

3) $\left(\mathrm{Y}_{0.87} \mathrm{Dy}_{0.09} \mathrm{Er}_{0.04} \mathrm{Gd}_{0.04} \mathrm{Yb}_{0.02}\right)_{1.06}\left[\mathrm{P}_{0.95} \mathrm{O}_{4}\right]$;

4) $\left(\mathrm{Y}_{0.80} \mathrm{Dy}_{0.11} \mathrm{Er}_{0.05} \mathrm{Gd}_{0.04} \mathrm{Yb}_{0.03}\right)_{1.03}\left[\mathrm{P}_{0.87} \mathrm{O}_{4}\right]$;

5) $\left(\mathrm{Y}_{0.60} \mathrm{Dy}_{0.06} \mathrm{Er}_{0.05} \mathrm{Gd}_{0.03} \mathrm{Yb}_{0.03}\right)_{0.77}\left[\mathrm{P}_{1.10} \mathrm{O}_{4}\right]$;

6) $\left(\mathrm{Y}_{0.69} \mathrm{Dy}_{0.08} \mathrm{Er}_{0.05} \mathrm{Gd}_{0.05} \mathrm{Yb}_{0.05} \mathrm{Eu}_{0.01}\right)_{0.93}\left[\mathrm{P}_{0.96} \mathrm{O}_{4}\right]$.

Кристалоохимическая формула ксенотима из переотложенной коры выветривания $\left(\mathrm{Y}_{0.78} \mathrm{Dy}_{0.06} \mathrm{Gd}_{0.03} \mathrm{Er}_{0.03} \mathrm{Yb}_{0.02}\right)_{0.92}\left[\mathrm{P}_{1.04} \mathrm{O}_{4}\right]$.

Фосфаты группы крандаллита встречаются в зонах гидратации и гидролиза остаточной коры выветривания, в зоне гидратации минералы представлены гояцитом, горсейкситом, флоренситом, крандал- 
литом, в зоне гидролиза - горсейкситом, флоренситом и плюмбогуммитом (рис. 6). Минералы имеют тесные взаимоотношения.

В зоне гидратации наиболее распространены гояциит и горсейксит (рис. 6, $c, d$ ). Как правило, минералы образуют совместные агрегаты переменного химического состава неправильной формы размером до 0,14-0,15 мм. Чаще всего гояцит занимает в этих агрегатах центральные части либо располагается тонкими параллельными полосами, внешняя, существенно бариевая зона - горсейксит, нарастает на кристаллы гояцита, в единичных агрегатах присутствуют реликтовые остатки крандаллита. Часто агрегаты минералов корродированны, крайне редко минералы встречаются отдельно - гояцит в виде корродированных зерен размером менее 0,08 мм, а также горсейксит в виде зерен размером менее 0,15 мм и хорошо образованных кристаллов псевдокубического облика размером до 0,2 мм. В зоне гидролиза горсейксит полностью замещает гояцит и встречается в виде единичных обломков кристаллов размером менее 0,1 мм. Минералы находятся в срастаниях с кварцем и каолинитом, реже гидрослюдой, в зоне гидратации в кристалле горсейксита установлено включение циркона.
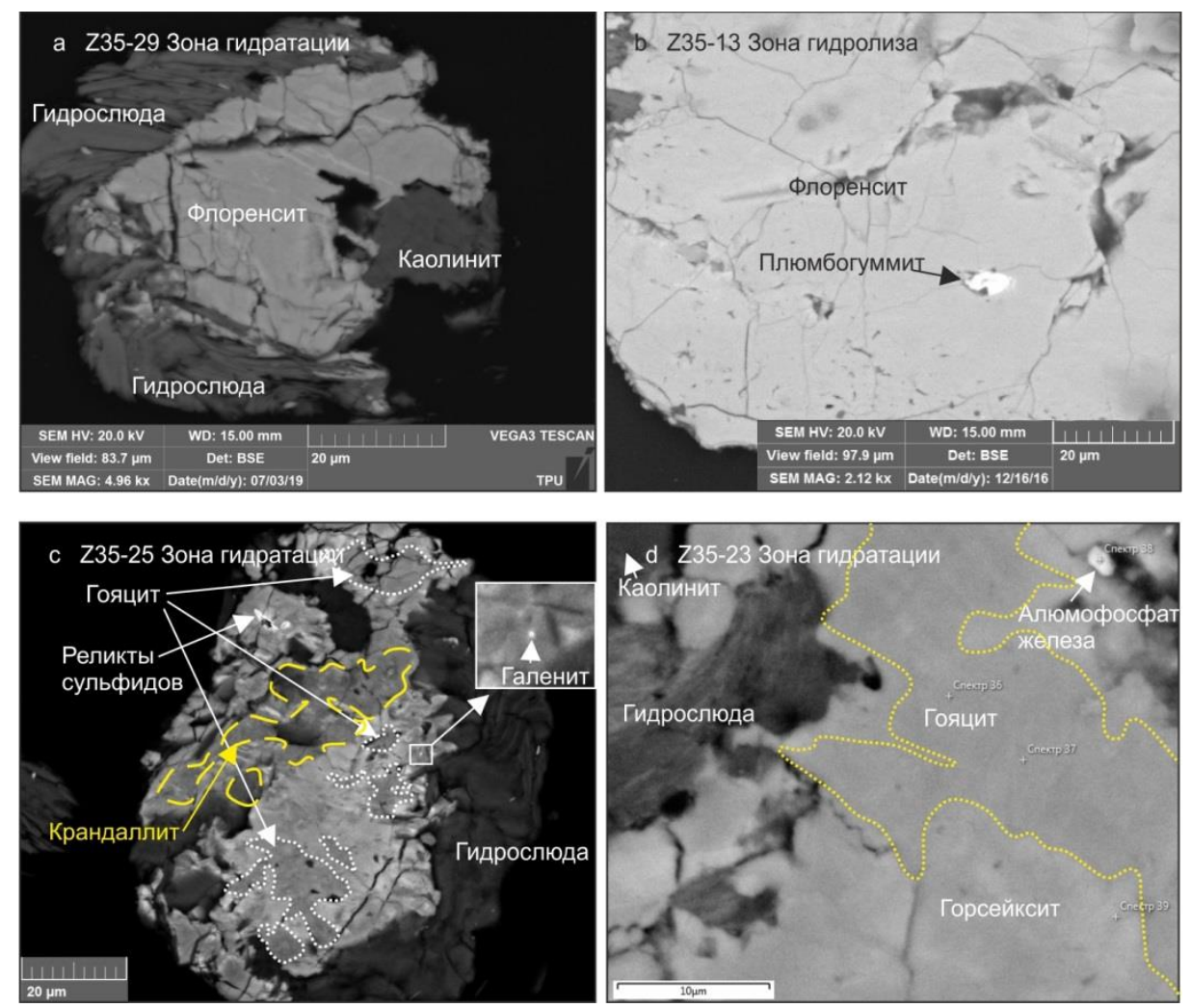

Рис. 6. Морфология агрегатов минералов группы крандаллита (a, $b$-образование флоренсита в зонах гидратации и гидролиза ОКВ, $c, d$-образование крандаллита, гояцита и горсейксита в зоне гидратации ОКВ)

Fig. 6. Morphology of aggregates of minerals of the crandallite group ( $a, b-$ the formation of florensite in the zones of hydration and hydrolysis of the residual weathering crust, $c, d$ - the formation of crandallite, goyacite and gorseixite in the hydration zone of the residual weathering crust)

По химическому составу в ряду гояцит-горсейксит распространены минералы с промежуточным химическим составом. Для минералов характерны значительные вариации в содержании элементов, содержание фосфора 29,64-33,84 \%, алюминия 25,59-34,51\%, в гояците стронций $(7,17-20,15 \%)$ преобладает над барием (1,70-10,78 \%), в горсейксите барий (12,64-24,63\%) доминирует над стронцием (3,19-9,60 \%). В структурной позиции стронция в виде изоморфной примеси практически, всегда присутствуют кальций (до $3,87 \%$ ) и редкоземельные элементы (церий - до 6,59 $\%$, лантан - до 3,79 \%, неодим - до 1,88 \%) (табл. 4). Наличие кальция свидетельствует о примеси молекулы крандаллита, редкоземельных элементов - об образовании за счет разрушения редкоземельных фосфатов - монацитов. Также в составе минералов часто присутствует фтор (до 4,65 \%), вероятно, наследуемый из состава апатита. Примеси, обусловленные вмещающими минералами, представлены кремнием, калием, титаном. Примеси свинца, железа и серы обусловлены включениями и реликтами сульфидов.

Кристалоохимические формулы гояцита (1-12) и горсейксита (13-23) зоны гидратации:

1) $\left(\mathrm{Sr}_{0.63} \mathrm{Ba}_{0.24} \mathrm{Ca}_{0.03}\right)_{1.79}\left(\mathrm{Al}_{2.71} \mathrm{Fe}_{0.01}\right)_{2.72}\left[\mathrm{PO}_{4}\right]\left[\mathrm{PO}_{2.34}(\mathrm{OH})\right] \times$ $\times\left(\mathrm{OH}_{5.93} \mathrm{~F}_{0.73}\right)$;

2) $\left(\mathrm{Sr}_{1.29} \mathrm{Ba}_{0.43} \mathrm{Ca}_{0.07}\right)_{1.79} \mathrm{Al}_{2.71}\left[\mathrm{PO}_{4}\right]\left[\mathrm{PO}_{1.99}(\mathrm{OH})\right]\left(\mathrm{OH}_{5.27} \mathrm{~F}_{0.73}\right)$;

3) $\left(\mathrm{Sr}_{0.72} \mathrm{Ba}_{0.15} \mathrm{Ca}_{0.04}\right)_{0.91} \mathrm{Al}_{3.00}\left[\mathrm{PO}_{4}\right]\left[\mathrm{PO}_{4.77}(\mathrm{OH})\right]\left(\mathrm{OH}_{3.70} \mathrm{~F}_{0.53}\right)$;

4) $\left(\mathrm{Sr}_{0.83} \mathrm{Ba}_{0.05}\right)_{0.88} \mathrm{Al}_{2.80}\left[\mathrm{PO}_{4}\right]\left[\mathrm{PO}_{2.14}(\mathrm{OH})\right]\left(\mathrm{OH}_{6.23} \mathrm{~F}_{0.63}\right)$;

5) $\left(\mathrm{Sr}_{0.54} \mathrm{Ce}_{0.20} \mathrm{La}_{0.11} \mathrm{Ba}_{0.09} \mathrm{Ca}_{0.08} \mathrm{Nd}_{0.05}\right)_{1.07}\left(\mathrm{Al}_{2.59} \mathrm{Fe}_{0.05}\right)_{2.64}$ $\left[\mathrm{PO}_{4}\right]\left[\mathrm{PO}_{2.91}(\mathrm{OH})\right]\left(\mathrm{OH}_{6.09}\right)$;

6) $\left(\mathrm{Sr}_{0.58} \mathrm{Ce}_{0.15} \mathrm{Ba}_{0.15} \mathrm{La}_{0.08} \mathrm{Ca}_{0.08} \mathrm{Nd}_{0.03}\right)_{1.07} \mathrm{Al}_{2.36}\left[\mathrm{PO}_{4}\right] \times$ $\times\left[\mathrm{PO}_{1.48}(\mathrm{OH})\right]\left(\mathrm{OH}_{7.52}\right)$; 
7) $\left(\mathrm{Sr}_{0.69} \mathrm{Ba}_{0.19} \mathrm{Ca}_{0.02}\right)_{0.91} \mathrm{Al}_{2.80}\left[\mathrm{PO}_{4}\right]\left[\mathrm{PO}_{2.20}(\mathrm{OH})\right]\left(\mathrm{OH}_{6.42} \mathrm{~F}_{0.38}\right)$;

8) $\left(\mathrm{Sr}_{0.56} \mathrm{Ba}_{0.30} \mathrm{Ca}_{0.03}\right)_{0.90} \mathrm{Al}_{2.80}\left[\mathrm{PO}_{4}\right]\left[\mathrm{PO}_{2.12}(\mathrm{OH})\right]\left(\mathrm{OH}_{6.41} \mathrm{~F}_{0.47}\right)$;

9) $\left(\mathrm{Sr}_{0.69} \mathrm{Ba}_{0.39} \mathrm{Ca}_{0.07}\right)_{1.15} \mathrm{Al}_{2.91}\left[\mathrm{PO}_{4}\right]\left[\mathrm{PO}_{2.64}(\mathrm{OH})\right]\left(\mathrm{OH}_{6.11} \mathrm{~F}_{0.26}\right)$;

10) $\left(\mathrm{Sr}_{0.78} \mathrm{Ba}_{0.09}\right)_{0.87} \mathrm{Al}_{2.83}\left[\mathrm{PO}_{4}\right]\left[\mathrm{PO}_{2.23}(\mathrm{OH})\right]\left(\mathrm{OH}_{6.10} \mathrm{~F}_{0.67}\right)$;

11) $\left(\mathrm{Sr}_{0.32} \mathrm{Ca}_{0.31} \mathrm{Ba}_{0.21}\right)_{0.86}\left(\mathrm{Al}_{2.97} \mathrm{Fe}_{0.12}\right)_{3.09}\left[\mathrm{PO}_{4}\right]\left[\mathrm{PO}_{3.67}(\mathrm{OH})\right] \times$ $\times\left(\mathrm{OH}_{5.33}\right)$;

12) $\left(\mathrm{Sr}_{0.34} \mathrm{Ca}_{0.32} \mathrm{Ba}_{0.19} \mathrm{Ce}_{0.05} \mathrm{La}_{0.02}\right)_{0.92}\left(\mathrm{Al}_{3.03} \mathrm{Fe}_{0.11}\right)_{3.14}\left[\mathrm{PO}_{4}\right] \times$ $\times\left[\mathrm{PO}_{4.83}(\mathrm{OH})\right]\left(\mathrm{OH}_{3.74} \mathrm{~F}_{0.43}\right)$;

13) $\left(\mathrm{Ba}_{0.44} \mathrm{Sr}_{0.37} \mathrm{Ca}_{0.11}\right)_{0.92} \mathrm{Al}_{2.22}\left[\mathrm{PO}_{4}\right]\left[\mathrm{PO}_{2.60}(\mathrm{OH})\right]\left(\mathrm{OH}_{5.84} \mathrm{~F}_{0.56}\right)$;

14) $\left(\mathrm{Ba}_{0.69} \mathrm{Sr}_{0.14} \mathrm{Ca}_{0.12}\right)_{0.95} \mathrm{Al}_{2.93}\left[\mathrm{PO}_{4}\right]\left[\mathrm{PO}_{2.70}(\mathrm{OH})\right]\left(\mathrm{OH}_{5.64} \mathrm{~F}_{0.67}\right)$;
15) $\left(\mathrm{Ba}_{0.38} \mathrm{Sr}_{0.35} \mathrm{Ca}_{0.10}\right)_{0.83}\left(\mathrm{Al}_{2.63} \mathrm{Fe}_{0.07}\right)_{2.70}\left[\mathrm{PO}_{4}\right]\left[\mathrm{PO}_{2.19}(\mathrm{OH})\right] \times$ $\times\left(\mathrm{OH}_{6.81}\right)$;

16) $\left(\mathrm{Ba}_{0.73} \mathrm{Sr}_{0.18} \mathrm{Ca}_{0.07}\right)_{0.98} \mathrm{Al}_{2.92}\left[\mathrm{PO}_{4}\right]\left[\mathrm{PO}_{2.72}(\mathrm{OH})\right]\left(\mathrm{OH}_{5.59} \mathrm{~F}_{0.68}\right)$;

17) $\left(\mathrm{Ba}_{0.58} \mathrm{Sr}_{0.29} \mathrm{Ca}_{0.09}\right)_{0.96} \mathrm{Al}_{2.90}\left[\mathrm{PO}_{4}\right]\left[\mathrm{PO}_{2.60}(\mathrm{OH})\right]\left(\mathrm{OH}_{6.03} \mathrm{~F}_{0.37}\right)$;

18) $\left(\mathrm{Ba}_{0.61} \mathrm{Sr}_{0.16} \mathrm{Ca}_{0.15}\right)_{0.92} \mathrm{Al}_{2.93}\left[\mathrm{PO}_{4}\right]\left[\mathrm{PO}_{2.65}(\mathrm{OH})\right]\left(\mathrm{OH}_{5.83} \mathrm{~F}_{0.52}\right)$;

19) $\left(\mathrm{Ba}_{0.77} \mathrm{Sr}_{0.15}\right)_{0.92} \mathrm{Al}_{2.94}\left[\mathrm{PO}_{4}\right]\left[\mathrm{PO}_{2.67}(\mathrm{OH})\right]\left(\mathrm{OH}_{5.66} \mathrm{~F}_{0.68}\right)$;

20) $\left(\mathrm{Ba}_{0.72} \mathrm{Sr}_{0.20} \mathrm{Ca}_{0.02}\right)_{0.96} \mathrm{Al}_{2.90}\left[\mathrm{PO}_{4}\right]\left[\mathrm{PO}_{2.53}(\mathrm{OH})\right]\left(\mathrm{OH}_{5.84} \mathrm{~F}_{0.63}\right)$;

21) $\left(\mathrm{Ba}_{0.56} \mathrm{Sr}_{0.27} \mathrm{Ca}_{0.15} \mathrm{~Pb}_{0.03}\right)_{1.01} \mathrm{Al}_{3.08}\left[\mathrm{PO}_{4}\right]\left[\mathrm{PO}_{3.27}(\mathrm{OH})\right] \times$ $\times\left(\mathrm{OH}_{5.06} \mathrm{~F}_{0.67}\right)$;

22) $\left(\mathrm{Ba}_{0.69} \mathrm{Sr}_{0.28}\right)_{0.98} \mathrm{Al}_{3.03}\left[\mathrm{PO}_{4}\right]\left[\mathrm{PO}_{3.02}(\mathrm{OH})\right]\left(\mathrm{OH}_{4.82} \mathrm{~F}_{1.16}\right)$;

23) $\left(\mathrm{Ba}_{0.50} \mathrm{Sr}_{0.41} \mathrm{Ca}_{0.03}\right)_{0.94} \mathrm{Al}_{2.86}\left[\mathrm{PO}_{4}\right]\left[\mathrm{PO}_{2.48}(\mathrm{OH})\right]\left(\mathrm{OH}_{6.09} \mathrm{~F}_{0.43}\right)$.

Таблица 4. Химический состав алюмофосфатов группь крандаллита из ОКВ

Table 4. Chemical composition of aluminophosphates of the crandallite group from the residual weathering crust

\begin{tabular}{|c|c|c|c|c|c|c|c|}
\hline \multirow{3}{*}{$\begin{array}{c}\text { Содержание ок- } \\
\text { сидов, \% } \\
\text { Content of } \\
\text { oxides, } \%\end{array}$} & \multicolumn{7}{|c|}{ Остаточная кора выветривания/Residual weathering crust } \\
\hline & \multicolumn{4}{|c|}{ Зона гидратации/Hydration zone } & \multicolumn{3}{|c|}{ Зона гидролиза/Hydrolysis zone } \\
\hline & $\begin{array}{c}\text { Горсейксит } \\
\text { Gorseixit }\end{array}$ & $\begin{array}{c}\text { Гояцит } \\
\text { Goyazite } \\
\end{array}$ & $\begin{array}{c}\text { Крандаллит } \\
\text { Crandallit }\end{array}$ & $\begin{array}{l}\text { Флоренсит } \\
\text { Florensite } \\
\end{array}$ & $\begin{array}{c}\text { Горсейксит } \\
\text { Gorseixit }\end{array}$ & $\begin{array}{l}\text { Флоренсит } \\
\text { Florensite } \\
\end{array}$ & $\begin{array}{c}\text { Плюмбогуммит } \\
\text { Plumbogumite }\end{array}$ \\
\hline $\mathrm{P}_{2} \mathrm{O}_{5}$ & $\frac{29,64-33,39}{30,87}$ & $\frac{29,00-33,84}{31,70}$ & 30,24 & $\frac{25,10-30,80}{27,43}$ & 30,57 & $\frac{26,90-29,32}{28,11}$ & 19,33 \\
\hline $\mathrm{Al}_{2} \mathrm{O}_{3}$ & $\frac{29,24-35,03}{32,29}$ & $\frac{25,59-34,51}{31,92}$ & 30,96 & $\frac{25,96-33,50}{28,94}$ & 31,55 & $\frac{27,66-30,10}{28,88}$ & 24,55 \\
\hline $\mathrm{SrO}$ & $\frac{3,29-9,60}{5,77}$ & $\frac{7,17-20,15}{14,22}$ & 4,78 & $\frac{2,90-5,52}{4,19}$ & 3,19 & $\frac{1,74-3,02}{2,38}$ & - \\
\hline $\mathrm{BaO}$ & $\frac{12,64-24,63}{20,15}$ & $\frac{1,70-10,78}{5,93}$ & 4,38 & $\frac{0,00-0,59}{0,15}$ & 23,05 & $\frac{0,00-2,08}{1,04}$ & - \\
\hline $\mathrm{PbO}$ & $\frac{0,00-1,34}{0,12}$ & $\frac{0,00-1,71}{0,14}$ & - & - & - & - & 31,86 \\
\hline $\mathrm{CaO}$ & $\frac{0,00-1,84}{0,94}$ & $\frac{0,00-3,87}{1,08}$ & 5,51 & $\frac{0,26-1,59}{1,01}$ & 1,30 & - & 0,21 \\
\hline $\mathrm{Ce}_{2} \mathrm{O}_{3}$ & $\frac{0,00-4,66}{0,42}$ & $\frac{0,00-6,59}{1,12}$ & 2,77 & $\frac{9,03-13,55}{10,94}$ & - & $\frac{13,69-13,96}{13,83}$ & 2,20 \\
\hline $\mathrm{La}_{2} \mathrm{O}_{3}$ & $\frac{0,00-2,32}{0,21}$ & $\frac{0,00-3,79}{0,61}$ & 1,82 & $\frac{4,54-6,07}{5,45}$ & - & $\frac{6,84-7,07}{6,96}$ & 1,09 \\
\hline $\mathrm{Pr}_{2} \mathrm{O}_{3}$ & - & - & - & $\frac{0,00-1,59}{0,91}$ & - & $\frac{1,26-1,62}{1,44}$ & - \\
\hline $\mathrm{Nd}_{2} \mathrm{O}_{3}$ & $\frac{0,00-1,88}{0,17}$ & $\frac{0,00-1,81}{0,25}$ & 0,90 & $\frac{2,43-5,51}{3,90}$ & - & $\frac{3,78-4,42}{4,10}$ & - \\
\hline $\mathrm{ThO}_{2}$ & - & - & - & $\frac{0,00-1,16}{0,29}$ & - & - & - \\
\hline $\mathrm{F}$ & $\frac{0,00-4,65}{2,38}$ & $\frac{0,00-3,31}{1,74}$ & - & - & 3,14 & - & - \\
\hline $\mathrm{FeO}$ & $\frac{0,00-1,15}{0,10}$ & $\frac{0,00-1,82}{0,36}$ & 1,93 & $\frac{0,57-3,27}{2,09}$ & - & - & - \\
\hline $\mathrm{Fe}_{2} \mathrm{O}_{3}$ & - & - & - & - & - & - & 0,91 \\
\hline $\mathrm{SO}_{3}$ & - & $\frac{0,00-1,08}{0,09}$ & 0,77 & $\frac{0,00-0,40}{0,11}$ & - & - & - \\
\hline $\mathrm{As}_{2} \mathrm{O}_{5}$ & - & - & - & - & - & - & 0,44 \\
\hline $\mathrm{Ta}_{2} \mathrm{O}_{5}$ & - & - & - & $\frac{0,00-1,40}{0,35}$ & - & - & - \\
\hline $\mathrm{SiO}_{2}$ & $\frac{0,00-1,62}{0,15}$ & $\frac{0,00-3,90}{0,84}$ & - & - & - & - & 0,98 \\
\hline $\mathrm{K}_{2} \mathrm{O}$ & $\frac{0,00-0,12}{0,01}$ & $\frac{0,00-0,86}{0,12}$ & 0,18 & - & - & - & - \\
\hline $\mathrm{TiO}_{2}$ & - & $\frac{0,00-2,63}{0,40}$ & - & - & - & - & - \\
\hline ¿Р3Э & $\frac{0,00-8,86}{0,81}$ & $\frac{0,00-12,19}{1,98}$ & 5,49 & $\frac{18,37-26,35}{21,20}$ & - & $\frac{25,80-26,84}{26,32}$ & 3,29 \\
\hline Сумма & $\frac{90,74-97,41}{93,60}$ & $\frac{83,68-96,58}{90,50}$ & 84,24 & $\frac{78,29-92,27}{85,74}$ & 92,80 & $\frac{84,18-89,28}{86,73}$ & 81,57 \\
\hline
\end{tabular}

Кристалоохимическая формула горсейксита зоны гидролиза имеет вид $\left(\mathrm{Ba}_{0.70} \mathrm{Sr}_{0.14} \mathrm{Ca}_{0.11}\right)_{0.95} \mathrm{Al}_{2.87}\left[\mathrm{PO}_{4}\right] \times$ $\times\left[\mathrm{PO}_{2.52}(\mathrm{OH})\right]\left(\mathrm{OH}_{5.71} \mathrm{~F}_{0.77}\right)$.

Крандаллит встречается только в зоне гидратации в виде единичных реликтов размером до 0,08 мм в центральных частях совместных агрегатов гояцитгорсейкситового состава (рис. $6, c)$.
По химическому составу для минерала характерен промежуточный между крандаллитом, гояцитом и горсейкситом состав с незначительным преобладанием кальция $(5,51 \%)$, содержание стронция и бария сопоставимо и составляет соответственно $4,78 \%$ и $4,38 \%$. Содержание фосфора составляет 30,24\%, алюминия - 30,96 \%. Также в составе минерала при- 
сутствуют редкоземельные элементы - церий, лантан, неодим. Примеси железа и серы обусловлены реликтами сульфидов, примесь калия - включениями слюды. Кристаллохимическая формула минерала $\left(\mathrm{Ca}_{0.46} \mathrm{Sr}_{0.22} \mathrm{Ba}_{0.13}\right)_{0.81}\left(\mathrm{Al}_{2.85} \mathrm{Fe}_{0.13}\right)_{2.98}\left[\mathrm{PO}_{4}\right]\left[\mathrm{PO}_{2.92}(\mathrm{OH})\right] \times$ $\times\left(\mathrm{OH}_{6.08}\right)$ (табл. 4).

Флоренсит встречается в зонах гидратации и гидролиза остаточной коры выветривания. В зоне гидратации установлен единичный агрегат минерала размером около 0,05 мм переменного химического состава. В зоне гидролиза флоренсит встречается в виде трещиноватых зерен неправильной формы размером менее 0,1 мм в срастании с рутилом, в одном зерне минерала встречен плюмбогуммит (рис. $6, a, b)$.

Большая часть минерала представлена флоренситом с содержанием фосфора - 25,1 \%, алюминия $26,56 \%$, общим содержанием редкоземельных элементов около $20 \%$, представленных церием $(9,03 \%)$, лантаном (6,07 \%), неодимом (2,43\%), празеодимом $(0,84 \%)$. Также в составе установлен торий $(1,16 \%)$. Содержание гояцитового - стронциевого, крандаллитового - кальциевого и горсейкситового - бариевого компонентов составляют соответственно 5,52, 1,59 и $0,59 \%$. Тонкие более светлые по тону полосы в агрегате характеризуются следующими содержаниями элементов: фосфора - 25,2-30,8 \%, алюминия 25,96-33,50 \%, церия - 9,91-13,55 \%, содержания лантана $(4,54-5,7 \%)$ и неодима $(3,25-5,51 \%)$ сопоставимы, содержание празеодима до 1,59 \%, стронция - 2,9-4,28 \%, кальция - 0,85-1,32 \%. Примеси железа и серы в составе минерала, возможно, обусловлены реликтами сульфидов, также присутствует примесь тантала (табл. 4).

В зоне гидролиза в составе минерала происходят изменения: снижается среднее содержание стронция до $2,38 \%$, увеличиваются содержания бария (до 1,04\%), церия (до 13,83 \%), незначительно увеличиваются содержания лантана (до 6,96 \%), неодима (до 4,10 \%), празеодима (до 1,44 \%). В составе минерала отсутствуют торий и кальций (табл. 4).

Флоренсит наследует закономерности состава от монацита, он представлен цериевой разновидностью с соотношением $\mathrm{Ce}>\mathrm{La}>\mathrm{Nd}$.

Кристалоохимические формулы флоренсита зон гидратации (1-4) и гидролиза $(5,6)$ :

1) $\left(\mathrm{Ce}_{0.34} \mathrm{Sr}_{0.23} \mathrm{La}_{0.19} \mathrm{Ca}_{0.13} \mathrm{Nd}_{0.11}\right)_{1.00}\left(\mathrm{Al}_{2.86} \mathrm{Fe}_{0.22}\right)_{3.08}\left[\mathrm{PO}_{4.22}\right]_{2} \times$ $\times\left(\mathrm{OH}_{5.56}\right)$;

2) $\left(\mathrm{Ce}_{0.41} \mathrm{La}_{0.17} \mathrm{Nd}_{0.16} \mathrm{Sr}_{0.14} \mathrm{Pr}_{0.05} \mathrm{Ca}_{0.02}\right)_{0.95}\left(\mathrm{Al}_{2.90} \mathrm{Fe}_{0.04}\right)_{2.94} \times$ $\times\left[\mathrm{PO}_{4.12}\right]_{2}\left(\mathrm{OH}_{5.77}\right)$;

3) $\left(\mathrm{Ce}_{0.32} \mathrm{Sr}_{0.18} \mathrm{La}_{0.13} \mathrm{Nd}_{0.12} \mathrm{Ca}_{0.07} \mathrm{Pr}_{0.03}\right)_{0.85}\left(\mathrm{Al}_{3.03} \mathrm{Fe}_{0.11}\right)_{3.14} \mathrm{X}$ $\times\left[\mathrm{PO}_{4.13}\right]_{2}\left(\mathrm{OH}_{5.75}\right)$;

4) $\left(\mathrm{Ce}_{0.31} \mathrm{Sr}_{0.30} \mathrm{La}_{0.21} \mathrm{Ca}_{0.16} \mathrm{Nd}_{0.08} \mathrm{Ta}_{0.04} \mathrm{Pr}_{0.03} \mathrm{Th}_{0.02} \mathrm{Ba}_{0.02}\right)_{1.17} \times$ $\times\left(\mathrm{Al}_{2.94} \mathrm{Fe}_{0.26}\right)_{3.20}\left[\mathrm{P}_{2.00} \mathrm{~S}_{0.03} \mathrm{O}_{9.42}\right]\left(\mathrm{OH}_{4.58}\right)$;

5) $\left(\mathrm{Ce}_{0.41} \mathrm{La}_{0.20} \mathrm{Sr}_{0.14} \mathrm{Nd}_{0.13} \mathrm{Pr}_{0.05}\right)_{0.93} \mathrm{Al}_{2.86}\left[\mathrm{PO}_{3.44}\right]_{2}\left(\mathrm{OH}_{7.12}\right)$;

6) $\left(\mathrm{Ce}_{0.44} \mathrm{La}_{0.23} \mathrm{Nd}_{0.12} \mathrm{Sr}_{0.21} \mathrm{Pr}_{0.04}\right)_{0.69} \mathrm{Al}_{2.86}\left[\mathrm{PO}_{4.23}\right]_{2}\left(\mathrm{OH}_{4.54}\right)$. Плюмбогуммит установлен только в зоне гидролиза в виде единичного зерна неправильной формы размером менее 0,01 мм в зерне флоренсита (рис. 7).

Минерал по химическому составу представляет собой водный алюмофосфат свинца с содержаниями фосфора 19,33 \%, алюминия - 24,55 \%, свинца $31,86 \%$. Также минерал содержит церий $(2,20 \%)$, лантан $(1,09 \%)$, незначительное количество кальция $(0,21 \%)$. Кристаллохимическая формула минерала $\left(\mathrm{Pb}_{1.05} \mathrm{Ce}_{0.10} \mathrm{La}_{0.05} \mathrm{Ca}_{0.03}\right)_{1.23} \mathrm{Al}_{3.54}\left[\mathrm{PO}_{4}\right]\left[\mathrm{PO}_{4.13}\right.$ $\left.(\mathrm{OH})_{0.95}\right]\left(\mathrm{OH}_{4.87}\right)$ (табл. 4).

В зоне гидратации был встречен алюмофосфат железа (предположительно, чилдренит) в виде овального короткопризматического зерна размером менее 0,05 мм в зерне алюмофосфата переменного гояцит-горсейкситового состава в срастании с гидрослюдой (рис. $6, d$ ).

По химическому составу минерал представляет собой алюмофосфат железа с содержанием железа - 37,2 \% и алюминия - 23,58 \%. В отличие от чилдренита в составе минерала наблюдается недостаток фосфора $(18,48 \%)$, который частично замещает кремний $(4,47 \%)$, также установлены барий $(8,86 \%)$, стронций $(6,27 \%)$, кальций $(0,58 \%)$ из вмещающего алюмофосфатого агрегата минералов, содержание воды в минерале не известно. Кристаллохимическая формула минерала $\mathrm{Fe}_{0.99} \mathrm{Al}_{0.89}\left(\mathrm{Sr}_{0.12} \mathrm{Ba}_{0.11} \mathrm{Ca}_{0.02}\right)_{0.25}\left[\mathrm{P}_{0.50} \mathrm{Si}_{0.14} \mathrm{O}_{4}\right]\left(\mathrm{OH}_{?}\right) \cdot ? \mathrm{H}_{2} \mathrm{O}$.

\section{Обсуждение результатов}

Проведенными исследованиями установлено, что во всех зонах остаточной коры выветривания и в переотложенной коре выветривания встречаются апатит и ксенотим, монацит - в зонах гидратации и гидролиза остаточной коры выветривания и переотложенной коре выветривания.

В зоне гидратации установлены водные алюмофосфаты - крандаллит, гояцит, горсейксит, флоренсит, в зоне гидролиза - горсейксит, флоренсит и плюмбогуммит.

Выявлено, что монацит, фтор-апатит и ксенотим являются наиболее устойчивыми минералами, в коре выветривания эти минералы остаются из исходных материнских пород - терригенных песчаников и алевролитов, в коре выветривания по дайке долеритов - только фтор-апатит. Гипергенные фосфаты представлены редкоземельными - монацитом и куларитом, а также алюмофосфатами группы крандаллита. Встречающиеся в переотложенной коре выветривания гипергенные монацит и куларит перемещены из зоны гидролиза остаточной коры выветривания.

Установленная последовательность преобразования первичных фосфатов представлена на рис. 7 . В зоне гидратации происходит образование алюмофосфатов - существенно кальциевого крандаллита, стронциевого гояцита, алюмофосфата редкоземельных металлов - флоренсита, при этом крандаллит по периферии замещается гояцитом, а гояцит - существенно бариевым горсейкситом. В зоне гидролиза горсейксит полностью замещает гояцит, а флоренсит - монацит, также здесь образуется гипергенный алюмофосфат свинца - плюмбогуммит. Горсейксит, флоренсит и плюмбогуммит являются минераламииндикаторами зоны гидролиза. Серная кислота, образующаяся при окислении сульфидных минералов, способствует разложению и растворению алюмосиликатов с выносом из их состава $\mathrm{Al}_{2} \mathrm{O}_{3}$ и фосфатов (первичных апатита, монацита) с образованием ряда 
алюмофосфатов в процессе гидратации (присоединения воды), при этом кальций и фтор в новообразованных минералах высвобождаются при разложении апатита, стронций и барий - возможно, полевых шпатов, редкоземельные металлы - монацита, свинец галенита, железо - пирита.

Присутствие в зоне гидратации мелких включений алюмофосфата железа, возможно, обусловлено обра- зованием его при разложении пирита и алюмосиликатных минералов.

В верхней части зоны гидролиза остаточной коры выветривания происходит образование гипергенных редкоземельных фосфатов - монацита, куларита и алюмофосфатов - горсейксита, флоренсита и плюмбогуммита. Здесь же отмечается наибольшее накопление золота (рис. 7).

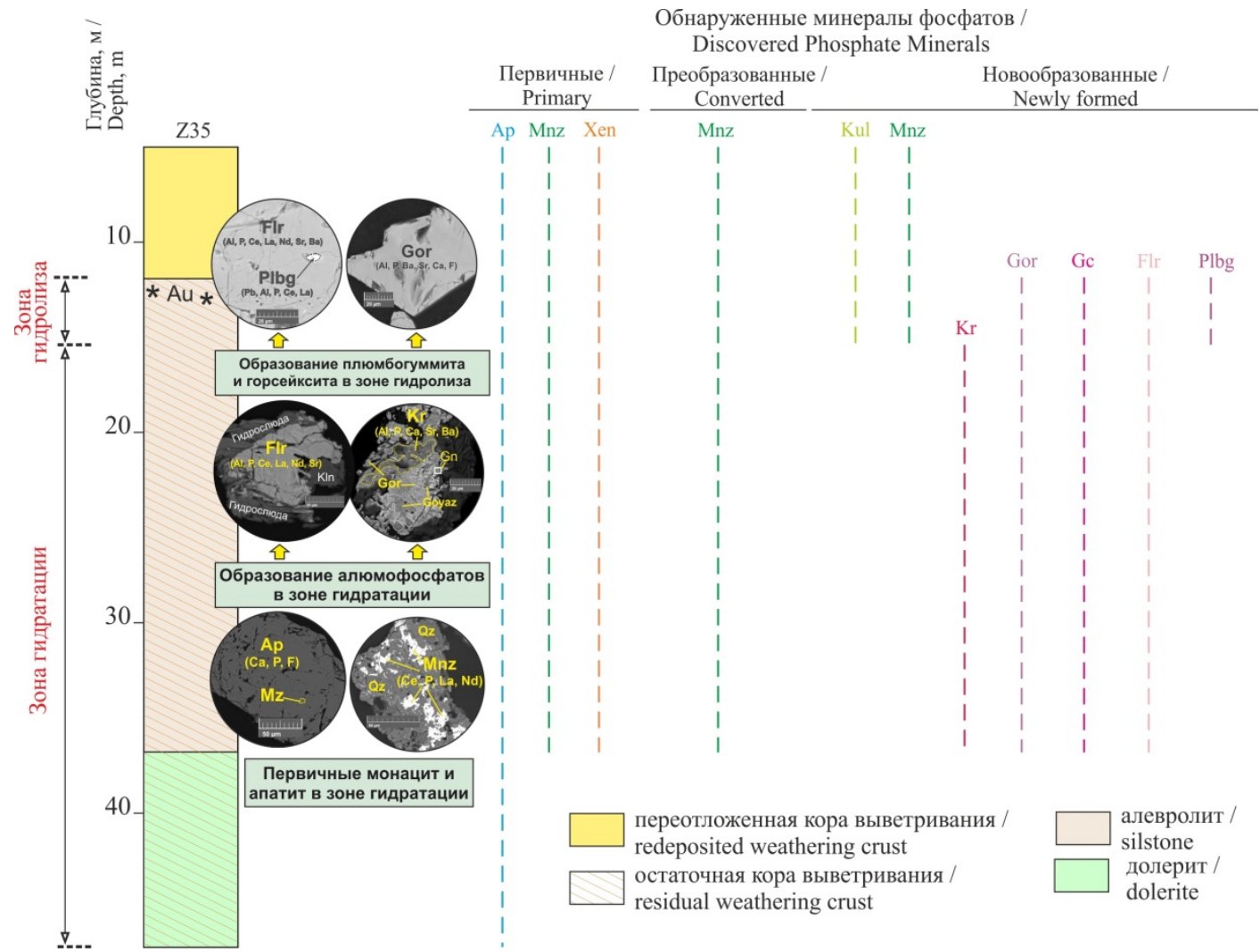

Рис. 7. Схема распространения фосфатов по разрезу коры выветривания и последовательного преобразования первичных фосфатов (апатита и моначита) с образованием гипергенных алюмофосфатов группы крандаллита (стрелками показана последовательность смены минералов, в скобках указаны основные элементы, содержащиеся в минералах). (Ар - апатит; Мnz - моначит; Хеп - ксенотим; Kul - куларит; Kr - крандаллит; Gor-горсейксит; Gc-гояичи; Flr-флоренсит; Plb-плюмбогуммит; Au-золото)

Fig. 7. Diagram of the distribution of phosphates along the section of the weathering crust and the successive transformation of primary phosphates (apatite and monazite) with the formation of hypergene alumophosphates of the crandallite group (arrows show the sequence of mineral changes, the main elements contained in minerals are indicated in brackets). (Ap - apatite; Mnz - monazite; Xen - xenotime; Kul - kularite; Kr - crandallite; Gor gorceixite; Gc-goyacite; Flr-florensite; Plb-plumbogumite; Au-gold)

\section{Заключение}

В результате проведенного комплекса детальных исследований кор выветривания Томского района установлены: 1) фосфаты группы апатита, 2) ортофосфаты редкоземельных элементов и тория и 3) алюмофосфаты группы крандаллита.

По генетическому признаку фосфатные минералы разделены на группы: а) первичные терригенные фосфаты, устойчивые в корах выветривания и выделившиеся при разрушении коренных пород (монацит, ксенотим, апатит), б) преобразованные, измененные в процессе выветривания (монацит), и в) новообразованные, образованные в процессе формирования кор выветривания (монацит, куларит, флоренсит, крандаллит, гояцит, горсейксит, плюмбогуммит).
Установленные в различных зонах коры выветривания ассоциации фосфатов большей частью представляют собой звенья последовательного преобразования минералов от кальциевых и редкоземельных фосфатов к алюминиевым, указывающего на возрастание кислотности среды минералообразования. В верхней части зоны гидролиза остаточной коры выветривания, где происходит образование гипергенных редкоземельных фосфатов (монацита, куларита) и алюмофосфатов (горсейксита, флоренсита, плюмбогуммита), отмечается наибольшее накопление золота.

Исследование выполнено при финансовой поддержке РФФИ и Администращии Томской области в рамках научного проекта № 18-45-700019. 


\section{СПИСОК ЛИТЕРАТУРЫ}

1. Valsami-Jones E. Phosphates // Encyclopedia of Geology. Elsevier, Academic Press, 2021. - P. 422-427.

2. Attfield J.P. Phosphates // Encyclopedia of Materials: Science and Technology. - Oxford, UK: Elsevier, 2001. - P. 6896-6901.

3. Apatite trace element compositions: a robust new tool for mineral exploration / M. Mao, A.S. Rukhlov, S.M. Rowins, J. Spence, L.A. Coogan // Economic Geology. - 2016. - V. 111. - № 5. P. 1187-1222.

4. Alunite supergroup: recommended nomenclature / P. Bayliss, U. Kolitsch, E.H. Nickel, A. Pring // Mineralogical Magazine. 2010. - V. 74. - № 5. - P. 919-927.

5. Haldar S.K., Tišljar J. Basic Mineralogy // Introduction to Mineralogy and Petrology. - 2014. - P. 338.

6. Фосфор в окружающей среде / Э. Гриффит, А. Битон, Д. Митчелл, Дж. Спенсер. - М.: Мир, 1977. - 760 с.

7. Becker P. Phosphates and phosphoric acid, raw materials, technology, and economics of the wet process. 2nd ed. - New York: Marcel Dekker, Inc., 1989. - 760 p.

8. Corbridge D.E.C. Phosphorus chemistry, biochemistry and technology. - Boca Raton: CRC Press, Taylor and Francis Group, 2013. - $1473 \mathrm{p}$

9. Jasinski S.M. Phosphate rock // U.S. Geological Survey Mineral Commodity Summaries. Reston: U.S. Geological Survey, 2011. P. 118-119.

10. Rare earth elements in sedimentary phosphate deposits: solution to the global REE crisis / P. Emsbo, P.I. McLaughlin, G.N. Breit, E.A. du Bray, A.E. Koenig // Gondwana Research. - 2015. V. 27. - P. 776-785.

11. Cordell D., Drangert J.-O., White S. The story of phosphorus: global food security and food for thought // Global Environmental Change. - 2009. - V. 19. - 292-305.

12. Heffer P., Prud'homme M. Short-term fertilizer outlook 2017-2021// IFA Strategic Forum. - Paris: International Fertilizer Industry Association (IFA), 2017. -5 p.

13. Stable soil organic matter: a comparison of $\mathrm{C}: \mathrm{N}: \mathrm{P}: \mathrm{S}$ ratios in Australian and other world soils / C.A. Kirkby, J.A. Kirkegaard, A.E. Richardson, L.J. Wade, C. Blanchard, G. Batten // Geoderma. 2011. - V. 163. - № 3-4. - P. 197-208.

14. Phosphorus and phosphorites - sedimentology and environments of formation / C.R. Glenn, K.B. Föllmi, S.R. Riggs, G.N. Baturin, K.A. Grimm, J. Trappe, A.M. Abed, C. Galli-Olivier, R.E. Garrison, A.V. Ilyin, C. Jehl, V. Rohrlich, R.M.Y. Sadaqah, M. Schidlowski, R.E. Sheldon, H. Siegmund // Eclogae Geologicae Helvetiae (Journal of the Swiss Geological Society). 1994. - V. 87. - P. 747-788.

15. Hiatt E.E., Budd D.A. Sedimentary phosphate formation in warm shallow waters: new insights into the palaeoceanography of the Permian Phosphoria Sea from analysis of phosphate oxygen isotopes // Sedimentary Geology. - 2001. - V. 145. - P. 119-133.

16. Prasad M.N.V. Resource potential of natural and synthetic gypsum waste // Environ Mater Waste. - 2016. - P. 307-337.

17. Bhattacharya A. Changing environmental condition and phosphorus-use efficiency in plants // Chang Clim Resour Use Effic Plants. - 2019. - P. 241-305.

18. Небытов В.Г. Влияние длительности последействия фосфорных удобрений и навоза на агрохимические свойства чернозёма выщелоченного и урожайность культур севооборота // Агрохимия. - 2005. - № 3. - С. 5-14.

19. Макаров М.И., Малышева Т.И. Фосфор в гумусовых кислотах // Почвоведение. - 2006. - Т. 39. - № 11. - С. 1208-1216.

20. Contrasting depth distribution of colloid-associated phosphorus in the active and abandoned sections of an alluvial fan in a hyper-arid region of the Atacama Desert / G. Moradi, R. Bol, L. Trbojevic, A. Missong, R. Mörchen, B. Fuentes, S.M. May, E. Lehndorff, E. Klumpp // Glob Planet Change. - 2020. - V. 185. - P. 1-8.

21. Leaching and recovery of phosphate and rare earth elements from an iron-rich fluorapatite concentrate. P. II: Selective leaching of calcium and phosphate and acid baking of the residue / F. Soltani, M. Abdollahy, J. Petersen, R. Ram, S.M. Javad Koleini, D. Moradkhani // Hydrometallurgy. - 2019. - V. 184. - P. 29-38.
22. Gupta C.K., Krishnamurthy N. Extractive metallurgy of rare earths // International Materials Reviews. - 1992. - V. 37 (1). - P. 197-248.

23. Review on hydrometallurgical recovery of rare earth metals A. Kumari, R. Panda, J. Rajesh Kumar, K. Yoo, J.Y. Lee // Hydrometallurgy. - 2016. - V. 165. - P. 2-26.

24. Zhang Y., Santos J. Crystallization and microstructure analysis of calcium phosphate-based glass ceramics for biomedical applications // Journal of Non-Crystalline Solids. - 2000. V. 272 - P. 14-21

25. Bioactive calcium phosphate-based glasses and ceramics and their biomedical applications / M.T. Islam, R.M. Felfel, E.A. Abou Neel, D.M. Grant, I. Ahmed, K.M.Z. Hossain // Journal of tissue engineering. -2017 . - V. 8. - P. 1-16.

26. Сафронова Т.В., Путляев В.И. Медицинское неорганическое материаловедение в России: кальцийфосфатные материалы // Наносистемы: физика, химия, математика. - 2013. - Т. 4. № 1. - C. $24-47$

27. Занин Ю.Н. Геохимические обстановки формирования парагенезов минералов фосфатсодержащих пород // Геология и геофизика - 1993. - Т. 34. - № 7. - С. 3-22.

28. McLennan S.M. Rare earth elements in sedimentary rocks influence of provenance and sedimentary processes // Reviews in Mineralogy. - 1989. - V. 21. - P. 169-200.

29. Contact metamorphic and metasomatic processes at the Kharaelakh intrusion, Oktyabrskoe deposit, Norilsk-Talnakh ore district: application of LA-ICPMS dating of perovskite, apatite, garnet and titanite / A.E. Marfin, A.V. Ivanov, V.S. Kamenetsky, A. Abersteiner, T.Y. Yakich // Economic Geology. - 2020. V. 115 (6) - P. 1213-1226

30. Cocherie A., Albarede F. An improved U-Th-Pb age calculation for electron microprobe dating of monazite // Geochimica et Cosmochimica Acta. - 2001. - V. 65. - P. 4509-4522.

31. Suzuki K., Kato T. CHIME dating of monazite, xenotime, zircon and polycrase: Protocol, pitfalls and chemical criterion of possibly discordant age data // Gondwana Research. - 2008. - V. 14. P. 569-586.

32. Пономарев В.С., Хиллер В.В., Ерохин Ю.В. Th-U-Pbдатирование монацита из метаморфических пород иткульской свиты Сысертского комплекса (Средний Урал) // Вестник Санкт-Петербургского университета. Науки о Земле. - 2019. T. 64. - № 2. - C. 315-327.

33. Минерально-геохимическая зональность золотоносных кор выветривания Томь-Яйского междуречья / О.М. Янченко, В.Г. Ворошилов, Т.В. Тимкин, М. Зиаии // Известия Томского политехнического университета. Инжиниринг георесурсов. 2019. - T. 330. - № 2. - C. 83-94.

34. Морфология и состав золота кор выветривания Томь-Яйского междуречья / О.М. Янченко, В.Г. Ворошилов, Т.В. Тимкин, И.В. Мартыненко, М. Зиаии // Известия Томского политехнического университета. Инжиниринг георесурсов. - 2019. T. 330. - № 3. - С. 84-92.

35. Черняев Е.В. Генезис и золотоносность кор выветривания Томского района // Цветные металлы и минералы: Сборник тезисов докладов восьмого международного конгресса. Красноярск: ООО «Научно-инновационный центр», 2016. C. 336-337.

36. Mineralogy of the Svetloye epithermal district, Okhotsk-Chukotka volcanic belt, and its insights for exploration / T.Y. Yakich, Y.S. Ananyev, A.S. Ruban, R.Y. Gavrilov, D.V. Lesnyak, D.V. Levochskaia, O.V. Savinova, M.A. Rudmin // Ore Geology Reviews. - 2021. - V. 136 (3). - 104257.

37. Петрохимическая характеристика кор выветривания Ольховско-Чибижекского района / И.В. Мартыненко, В.Г. Ворошилов, Т.В. Тимкин, М. Зиаии // Известия Томского политехнического университета. Инжиниринг георесурсов. - 2018. T. 329. - № 12. - C. 136-144.

38. Pshenichkin A., Timkin T., Oskina Y. Noble metals in rocks and ores of Maysko-Lebed ore field (Mountain Shoriya) // IOP Conference Series: Earth and Environmental Science. - 2015. V. 24. - P. 1-6. 


\section{Информация об авторах}

Янченко О.М., аспирант Инженерной школы природных ресурсов Национального исследовательского Томского политехнического университета.

Tимкин T.B., кандидат геолого-минералогических наук, доцент отделения геологии Инженерной школы природных ресурсов Национального исследовательского Томского политехнического университета.

Ворошилов В.Г., доктор геолого-минералогических наук, профессор Инженерной школы природных ресурсов Национального исследовательского Томского политехнического университета.

Якич T.Ю., кандидат геолого-минералогических наук, доцент отделения геологии Инженерной школы природных ресурсов Национального исследовательского Томского политехнического университета.

Зиаии M., $\mathrm{PhD}$, доцент Шахрудского технологического университета. 
UDC 551.311.231:553.086

\title{
NATURE OF PHOSPHATE DISTRIBUTION WITHIN THE GOLDEN WEATHERING CRUSTS OF THE TOMSK REGION
}

\author{
Olga M. Yanchenko', \\ olmininayanchenko@mail.ru \\ Timofey V. Timkin ${ }^{1}$, \\ timkin@tpu.ru
}

Valery G. Voroshilov ${ }^{1}$ v_g_v@tpu.ru

Tamara Yu. Yakich', cherkasovatu@tpu.ru

Mansour Ziaii ${ }^{2}$ m.ziaii47@gmail.com

1 National Research Tomsk Polytechnic University, 30, Lenin avenue, Tomsk, 634050, Russia.

2 Shahrood University of Technology, Bolvar Daneshka, Shahrood, 3619995161, Iran.

The relevance of the research. In the Tomsk region, the weathering crusts are very widespread, their gold content has been established, but a detailed study of the mineral composition has not previously been carried out. The relevance of the research is caused by the need to identify the conditions for formation of weathering crusts and to establish the patterns of accumulation of a wide range of minerals in them. The main aim of the research is to study the morphological and chemical features, paragenetic associations and distribution of minerals of the phosphate group, division into primary, transformed, and newly formed, the use of phosphates as minerals-indicators of the conditions for the formation of weathering crusts and their relationship with the distribution of gold.

The object: residual and redeposited weathering crusts of the Tomsk region and the minerals of the phosphate group contained in them. Methods. The crystal morphological features of minerals of the phosphate group, their paragenetic associations were studied microscopically using an OLYMPUS SZX10 stereomicroscope, the chemical composition of minerals was determined using a HORIBA Scientific XGT-7200 X-ray fluorescence microscope and a TESCAN VEGA 3 SBU X-50 X-50 EDS Max OXFORD scanning electron microscope.

Results. In the weathering crusts of the Tomsk region, phosphates of the apatite group, rare earth elements, and aluminophosphates of the crandallite group have been found. Phosphate minerals are divided into groups: primary terrigenous phosphates, stable in weathering crusts and released during the destruction of bedrock (monazite, xenotime, apatite), hypergene-transformed, altered during weathering (monazite), and secondary (monazite, cularite, flitorensite, crandallite, goyacite, gorseixite, plumbogumite). Established in different zones of the weathering crust, phosphate associations for the most part represent links in the successive transformation of minerals from calcium and rare-earth phosphates to aluminum, indicating an increase in the acidity of the mineral formation environment. In the upper part of the hydrolysis zone of the residual weathering crust, the greatest accumulation of gold is noted.

\section{Key words:}

Phosphates, weathering crust, mineralogical analysis, scanning electron microscopy, Kolyvan-Tomsk folded zone, Tomsk region.

The research was funded by RFBR and Tomsk region, project number 18-45-700019.

\section{REFERENCES}

1. Valsami-Jones E. Phosphates. Encyclopedia of Geology. Elsevier, Academic Press, 2021. pp. 422-427.

2. Attfield J.P. Phosphates. Encyclopedia of Materials: Science and Technology. Oxford, UK, Elsevier, 2001. pp. 6896-6901.

3. Mao M., Rukhlov A.S., Rowins, S.M., Spence, J., Coogan, L.A. Apatite trace element compositions: a robust new tool for mineral exploration. Economic Geology, 2016, vol. 111, no. 5, pp. 1187-1222.

4. Bayliss P., Kolitsch U., Nickel E.H., Pring A. Alunite supergroup recommended nomenclature. Mineralogical Magazine, 2010, vol. 74, no. 5, pp. 919-927.

5. Haldar S.K., Tišljar J. Basic Mineralogy. Introduction to Mineralogy and Petrology, 2014, pp. 338.

6. Griffith E., Beaton A., Mitchell D., Spencer J. Fosfor $v$ okruzhayushchey srede [Phosphorus in the environment]. Moscow, Mir Publ., 1977. 760 p.
7. Becker P. Phosphates and phosphoric acid, raw materials, technology, and economics of the wet process. $2^{\text {nd }}$ ed. New York, Marcel Dekker, Inc., 1989. $760 \mathrm{p}$.

8. Corbridge D.E.C. Phosphorus chemistry, biochemistry and technology. Boca Raton, CRC Press, Taylor and Francis Group, 2013. $1473 \mathrm{p}$

9. Jasinski S.M. Phosphate rock. U.S. Geological Survey Mineral Commodity Summaries. Reston, U.S. Geological Survey, 2011. pp. 118-119.

10. Emsbo P., McLaughlin P.I., Breit G.N., Du Bray E.A., Koenig A.E. Rare earth elements in sedimentary phosphate deposits: Solution to the global REE crisis. Gondwana Research, 2015, vol. 27, pp. 776-785.

11. Cordell D., Drangert J.-O., White S. The story of phosphorus: global food security and food for thought. Global Environmental Change, 2009, vol. 19, pp. 292-305.

12. Heffer P., Prud'homme M. Short-term fertilizer outlook 2017-2021. IFA Strategic Forum. Paris, International Fertilizer Industry Association (IFA), 2017. 5 p. 
13. Kirkby C.A., Kirkegaard J.A., Richardson A.E., Wade L.J. Blanchard C., Batten G. Stable soil organic matter: a comparison of C:N:P:S ratios in Australian and other world soils. Geoderma, 2011, vol. 163, no. 3-4, pp. 197-208.

14. Glenn C.R., Föllmi K.B., Riggs S.R., Baturin G.N., Grimm K.A., Trappe J., Abed A.M., Galli-Olivier C., Garrison R.E., Ilyin A.V., Jehl C., Rohrlich V., Sadaqah R.M.Y., Schidlowski M., Sheldon R.E., Siegmund $\mathrm{H}$. Phosphorus and phosphorites - sedimentology and environments of formation. Eclogae Geologicae Helvetiae (Journal of the Swiss Geological Society), 1994, vol. 87, pp. 747-788.

15. Hiatt E.E., Budd D.A. Sedimentary phosphate formation in warm shallow waters: new insights into the palaeoceanography of the Permian Phosphoria Sea from analysis of phosphate oxygen isotopes. Sedimentary Geology, 2001, vol. 145, pp. 119-133.

16. Prasad M.N.V. Resource potential of natural and synthetic gypsum waste. Environ Mater Waste, 2016, pp. 307-337.

17. Bhattacharya A. Changing environmental condition and phosphorus-use efficiency in plants. Chang Clim Resour Use Effic Plants, 2019, pp. 241-305.

18. Nebytov V.G Vliyanie dlitelnosti posledejstviya fosfornyh udobrenij i navoza na agrohimicheskie svojstva chernozyoma vyshchelochennogo i urozhajnost kultur sevooborota. [Influence of the duration of the aftereffect of phosphorus fertilizers and manure on the agrochemical properties of leached chernozem and crop yield]. Agrokhimiya, 2005, vol. 3, pp. 5-14.

19. Makarov, M.I., Malysheva, T.I. Phosphorus in humus acids. Eurasian Soil Science, 2006, vol. 39, no. 11, pp. 1208-1216.

20. Moradi G., Bol R., Trbojevic L., Missong A., Mörchen R., Fuentes B., May S.M., Lehndorff E., Klumpp E. Contrasting depth distribution of colloid-associated phosphorus in the active and abandoned sections of an alluvial fan in a hyper-arid region of the Atacama Desert. Glob Planet Change, 2020. vol. 185, pp. 1-8.

21. Soltani F., Abdollahy M., Petersen J., Ram R., Javad Koleini S.M., Moradkhani D. Leaching and recovery of phosphate and rare earth elements from an iron-rich fluorapatite concentrate. P. II: Selective leaching of calcium and phosphate and acid baking of the residue. Hydrometallurgy, 2019, vol. 184, pp. 29-38.

22. Gupta C.K., Krishnamurthy N. Extractive metallurgy of rare earths. International Materials Reviews, 1992, vol. 37 (1), pp. 197-248.

23. Kumari A., Panda R., Rajesh Kumar J., Yoo K., Lee J.Y. Review on hydrometallurgical recovery of rare earth metals. Hydrometallurgy, 2016, vol. 165, pp. 2-26.

24. Zhang Y., Santos J. Crystallization and microstructure analysis of calcium phosphate-based glass ceramics for biomedical applications. Journal of Non-Crystalline Solids, 2000, vol. 272, pp. 14-21.

25. Islam M.T., Felfel R.M., Abou Neel E.A., Grant D.M., Ahmed I., Hossain K.M.Z. Bioactive calcium phosphate-based glasses an ceramics and their biomedical applications: Journal of tissue engineering, 2017, vol. 8, pp. 1-16.

26. Safronova T.V., Putlyaev V.I. Inorganic materials science for medicine in Russia: materials based on calcium phosphates. Nanosystems: physics, chemistry, mathematics, 2013. vol. 4, no. 1, pp. 24-47.
27. Zanin Yu.N. Geohimicheskie obstanovki formirovaniya paragenezov mineralov fosfatsoderzhashchih porod [Geochemical environments of the formation of mineral parageneses of phosphate-bearing rocks]. Russian Geology and Geophysics, 1993. vol. 34, no. 7, pp. 3-22.

28. McLennan S.M. Rare earth elements in sedimentary rocks, influence of provenance and sedimentary processes. Reviews in Mineralogy, 1989, vol. 21, pp. 169-200.

29. Marfin A.E., Ivanov A.V., Kamenetsky V.S., Abersteiner A., Yakich T.Y. Contact metamorphic and metasomatic processes at the Kharaelakh intrusion, Oktyabrskoe deposit, Norilsk-Talnakh ore district: application of LA-ICPMS dating of perovskite, apatite, garnet and titanite. Economic Geology, 2020, vol. 115, no. 6, pp. 1213-1226.

30. Cocherie A., Albarede F. An improved U-Th-Pb age calculation for electron microprobe dating of monazite. Geochimica et Cosmochimica Acta, 2001, vol. 65, pp. 4509-4522.

31. Suzuki K., Kato T. CHIME dating of monazite, xenotime, zircon and polycrase: Protocol, pitfalls and chemical criterion of possibly discordant age data. Gondwana Research, 2008, vol. 14, pp. 569-586.

32. Ponomarev V.S., Khiller V.V., Erokhin Y.V. Th-U-Pb-dating of monazite from the metamorphic rocks of the itkul formation of the Sysert Metamorphic Complex (Middle Urals). Vestnik of Saint Petersburg University. Earth Sciences, 2019, vol. 64, pp. 315-327.

33. Yanchenko O.M., Voroshilov V.G., Timkin T.V., Ziaii M. Mineral-geochemical zonality of golden bearing weathering crust of the Tom-Yaya interfluve. Bulletin of the Tomsk Polytechnic University. Geo Assets Engineering, 2019, vol. 330, no. 2, pp. 83-94.

34. Yanchenko O.M., Voroshilov V.G., Timkin T.V., Martynenko I.V., Ziaii M. Morphology and composition of gold in weathering crust of the Tom-Yaya interfluve. Bulletin of the Tomsk Polytechnic University, Geo Assets Engineering, 2019, vol. 330, no. 3, pp. 84-92.

35. Chernyaev E.V. Genezis i zolotonosnost kor vyvetrivaniya Tomskogo rayona [Genesis and gold content of the weathering crust of the Tomsk region]. Tsvetnye metally $i$ mieraly. Sbornik tezisov dokladov 8 mezhdunarodnogo kongressa [Non-ferrous metals and minerals. Collection of abstracts of the eighth international congress]. Krasnoyarsk, Science and Innovation Center Publ. House, 2016. pp. 336-337.

36. Yakich T.Y., Ananyev Y.S., Ruban A.S., Gavrilov R.Y., Lesnyak D.V., Levochskaia D.V., Savinova O.V., Rudmin M.A. Mineralogy of the Svetloye epithermal district, Okhotsk-Chukotka volcanic belt, and its insights for exploration. Ore Geology Reviews, 2021 vol. 136, no. 3, 104257.

37. Martynenko I.V., Voroshilov V.G., Timkin T.V., Ziaii M. Petrochemical characterization of weathering crusts of OlkhovskChibizhek district. Bulletin of the Tomsk Polytechnic University. Geo Assets Engineering, 2018, vol. 329, no. 12, pp. 136-144.

38. Pshenichkin A., Timkin T., Oskina Y. Noble metals in rocks and ores of Maysko-Lebed ore field (Mountain Shoriya). IOP Conference Series: Earth and Environmental Science, 2015, vol. 24, pp. 1-6.

\section{Information about the authors}

Olga M. Yanchenko, postgraduate student, National Research Tomsk Polytechnic University.

Timofey V. Timkin, Cand. Sc., associate professor, National Research Tomsk Polytechnic University.

Valery G. Voroshilov, Dr. Sc., professor, National Research Tomsk Polytechnic University.

Tamara Yu. Yakich, Cand. Sc., associate professor, National Research Tomsk Polytechnic University.

Mansour Ziaii, PhD., associate professor, Shahrood University of Technology. 